\title{
Stability improvement and control of grid-connected photovoltaic system during faults using supercapacitor
}

\author{
I. Hamdan ${ }^{1}$ (D) Amira Maghraby ${ }^{2} \cdot$ Omar Noureldeen $^{1}$ (I)
}

Received: 25 September 2019 / Accepted: 20 November 2019 / Published online: 26 November 2019

(c) Springer Nature Switzerland AG 2019

\begin{abstract}
This paper describes the stability improvement of grid-connected photovoltaic (PV) system using supercapacitor (SC). The proposed technique is applied on PV system which using maximum power point tracking of perturbation and observation $(P \& O)$ algorithm. The P\&O algorithm is used to extract the maximum power from the studied PV system. The effect of SC as a type of storage device on PV system appears at the abnormal conditions of grid faults. This technique is used to compensate the system parameters at different fault conditions. The control strategy of SC technique is developed for continuously charging and discharging to achieve its objective. In addition, the control system is presented in order to maintain the DC link voltage and to manage the power transit between the SC and the grid. The whole grid-connected PV system with SC energy storage system (ESS) is modeled and simulated using MATLAB/SIMULINK software and also the control system strategies are demonstrated. The effects of different fault conditions on the behaviors of studied grid-connected PV system with the SC ESS technique are investigated. A comparison between the behaviors of studied PV system in cases of without SC and with SC technique is studied. Also, the variations of DC voltage, active power, and reactive power for the studied PV system equipped without and with SC technique are investigated. The simulation results present a clear improvement for the system stability in case of using SC. Numerical results illustrate the validity of proposed technique with satisfactory values.
\end{abstract}

Keywords Photovoltaic (PV) - Supercapacitor (SC) - Maximum power point tracking (MPPT) · Pulse width modulation (PWM) - Grid faults · Stability and control

\section{List of symbols}

$I_{D} \quad$ Diode current (A)

$I_{\text {sh }} \quad$ Shunt resistance current (A)

$I_{0} \quad$ Reverse saturation current (A)

$I_{g} \quad$ Light current of PV (A)

$l_{P V} \quad$ Generated current of PV (A)

$n_{p} \quad$ Numbers of PV modules in parallel

$n_{s} \quad$ Numbers of PV modules in series

$n_{c} \quad$ Series arranged PV cells

$r_{s h} \quad$ Shunt resistance of PV cell $(\Omega)$

$r_{s} \quad$ Series resistance of PV cell $(\Omega)$

$q \quad$ Electron charge $(1.6 \times 10-19 \mathrm{C})$

$k$ Boltzmann constant $(1.38 \times 10-23 \mathrm{~J} / \mathrm{K})$

$T$
$A$
$\delta$
$V_{P V}$
$V_{d c}$
$L$
$P_{g r i d}$
$P_{S C}$
$W_{E S S}$
$P_{P V}$
$C_{S C}$
$R$
$I_{L}$

Cell temperature $(\mathrm{K})$

Ideality factor of the diode (1.5-3)

Duty cycle of PWM

Output voltage of PV cells (V)

Output DC voltage of boost converter (V)

Inductance of boost converter $(\mathrm{H})$

Power of grid side $(\mathrm{kW})$

Exchanged power of SC (kW)

Storage energy of SC $(J)$

Generated power of PV (kW)

Capacitance of SC (F)

Internal resistance of boost converter $(\Omega)$

Inductor current of boost converter $(\mathrm{H})$

I. Hamdan, IbrahimHamdan86@eng.svu.edu.eg| ${ }^{1}$ Department of Electrical Engineering, Faculty of Engineering, South Valley University, Qena 83523, Egypt. ${ }^{2}$ Thebes academy, Qena 83523, Egypt. 


\begin{tabular}{|c|c|}
\hline$C_{P V}$ & Capacitance of input filter (F) \\
\hline$C_{d c}$ & Capacitance of DC link side (F) \\
\hline$I_{d c}$ & Output current of boost converter (A) \\
\hline$r_{t}$ & Resistance of inverter filter $(\Omega)$ \\
\hline$e_{t}$ & Inductance of inverter filter $(\mathrm{H})$ \\
\hline$V_{d \_m}, V_{q_{-} m}$ & $\begin{array}{l}\text { Measured } d-q \text { axis components of grid } \\
\text { voltages }(k V)\end{array}$ \\
\hline$V_{d c o n v}, V_{\text {qconv }}$ & $\begin{array}{l}\text { Converted } d-q \text { axis components of } \\
\text { inverter voltages }(k V)\end{array}$ \\
\hline$V_{\text {dcref }}$ & Reference DC voltage (V) \\
\hline$V_{A}, V_{B}$ and $V_{C}$ & Real three phase voltages of grid side $(\mathrm{kV})$ \\
\hline$\beta t$ & Phase angle (deg) \\
\hline$K_{p}$ and $K_{l}$ & $\begin{array}{l}\text { PI controller gains of inverter current } \\
\text { regulator }\end{array}$ \\
\hline$K_{P d c}$ and $K_{l d c}$ & $\begin{array}{l}\text { PI controller gains of inverter voltage } \\
\text { regulator }\end{array}$ \\
\hline$i_{d_{-} r e f}, i_{q_{-} r e f}$ & $\begin{array}{l}\text { Reference } d-q \text { axis component of grid } \\
\text { current (A) }\end{array}$ \\
\hline$i_{d_{-} m}, i_{q_{-} m}$ & $\begin{array}{l}\text { Measured } d-q \text { axis component of grid } \\
\text { current (A) }\end{array}$ \\
\hline$t$ & Charge and discharge time of SC (s) \\
\hline$V_{S C}$ & Voltage of SC (V) \\
\hline$U_{P W M}$ & $\begin{array}{l}\text { PWM control signal of bidirectional con- } \\
\text { verter circuit }\end{array}$ \\
\hline stre & Reference current of SC (A) \\
\hline & Current of SC (A) \\
\hline$K_{P 1}$ and $K_{/ 1}$ & $\begin{array}{l}\text { PI controller gains of } \mathrm{SC} \text { bidirectional } \\
\text { converter voltage regulator }\end{array}$ \\
\hline$K_{P 2}$ and $K_{12}$ & $\begin{array}{l}\text { PI controller gains of bidirectional con- } \\
\text { verter current regulator }\end{array}$ \\
\hline
\end{tabular}

\section{Introduction}

Renewable energy is considered the most popular alternative solution of electrical power that depends on the change in weather conditions. PV system is the most common source of renewable energies in the world. PV is a power source which mainly converts the solar power to electrical power. For this reason, the studies of PV systems are increasing rapidly in the recent times. It is also has its popularity because of many features, as it generates energy where the sun is shining brightly, has a lifelong cycle, it not have moving parts so it has a low cost maintenance. Furthermore there are considered the most clean, flexible and natural power resource [1]. The maximum benefits of power is realized by controlling the generated energy when it passes through a converter stage of DC/DC type with MPPT control unit to get the extreme benefits from the system [2]. The MPPT techniques that are used to track PV power over its maximum point at which the $\mathrm{PV}$ arrays releases the maximum energy for a certain irradiation and temperature. MPPT techniques have several types some of them are $\mathrm{P} \& \mathrm{O}$, hill-climbing and incremental conductance [3]. Thermal management is a major issue for the PVs and some cooling techniques were introduced to overcome this problem [4-6]. The reduction of electricity suppling might causes a lot of problems, so many efforts are focused to improve the grid connected PV system performance to get the maximum benefits of $P V$ farms at all operating conditions to fill the consumers' needs for energy at all time. There are a lot of instances to develop new techniques for storage the electricity of PV systems. These efforts study the techniques called ESS to storage the energy using different methods as batteries, superconducting magnetic energy units and SC [7]. ESS is an energy storage method that is used as a backup to achieve the balance between customer side of grid and generator side of PVs [8]. Some methodologies work on the investigation of the aim to storage the generated power from the renewable energy resources, so this field takes a huge attention of researchers. Belfedhal et al. [9] and Jacob et al. [10] have studied the performance of batteries as an energy storage device in different shapes and models. Hu et al. [11] has discussed the hybrid of wind/PV system performance using battery. Battery has a high cost and a slow charging and discharging device. It has a high effectiveness, long time to charge and a short time to discharge also it works at a short time. Shi et al. [12] and Sun et al. [13] have investigated the behavior of an energy generated system with superconducting magnetic energy storage as a type of ESS technique, which can store the energy in a magnetic field that is produced DC flowing through the superconducting coil. Li et al. [14] has discussed the superconducting magnetic energy storage device based on control mode for PV with grid connected systems that effectively improve the stability of system during low voltage ride through (LVRT). Vargas et al. [15] and Roy et al. [16] discuss the behavior of PV system with SC connection. Wang et al. [7] and Tian et al. [17] have analyzed the stability of multi-machines power system with fault applying on hybrid wind/PV farm using ESS unit based on SC. Mohammadi et al. [18] and Qiu et al. [19] have studied the effect of LVRT conditions on the performance of single phase grid connected PV using SC. Noureldeen et al. [20] has study how to save a constant active and reactive power from the wind farm during gust using the SC. Sedaghati and Shakarami [21] has analyzed the performance of a PV system using both battery and SC. The previous methodologies discussed several types of ESS and the impacts of this technique on the performance of different energy systems stability at its operating conditions. Clearly, each technique has certain characteristics and functions that make it unique from other energy storage devices with different kinds of systems. Also, SC has many advantages than other types as batteries as it has much larger energy 
density than the normal electrolytic capacitor, and it has a faster discharging and charging capability than batteries and it used in many energy system applications [22].

This paper methodology presents an extensive view of the stability improvement of $400 \mathrm{~kW}$ grid-connected PV system during the different fault types using $\mathrm{SC}$ technique. It conveys that the SC technique considers one of the most effective way that is used in the renewable energy systems for the purpose of power optimization. It is directly parallel connected with the capacitor of DC link side to work on store the PV ultra-energy then discharging it to the $\mathrm{DC}$ side to resist and compensate the voltage drop of system. SC is an energy storage device that has the ability of storage the excess energy from system and restores it at fault condition also at any needed time, using electronic charging and discharging means at different control times. The current work aims to study SC technique that will examine the stability of system and the improvement of output power fluctuating during the abnormal conditions at any point of system. Also, the system performance is investigated based on the fault duration for tripping or not tripping during voltage dips at which depends on the grid code recommendations that called LVRT. The impact of SC is significantly studied on system through saving the voltage profile at a fixed value on the abnormal conditions. This strategy also investigates the effect reduction of fault system on DC voltage fluctuating and hold it on its MPP value as well. It must also be noted that, there are many faults occur at different times that caused the dropping and falling in the system stability. The AC faults near grid side are considered the major problem that causes a huge drop on the reliability of PV operating system. The research is simulated using MATLAB/Simulink for the performance of grid-connected PV system. The simulation study compares between the system parameters in cases of with and without connection of SC to the studied system at AC faults conditions. The rest of the paper is organized as follows, Sect. 2 shows the general construction and modeling of grid-connected PV system. In Sect. 3 discusses the construction of SC model and its control unit. Section 4 explains the Egyptian fault ride through (FRT) capability for solar PV system. In Sect. 5 describes the studied PV system with SC model. Section 6 discusses the simulation results. Section 7 presents the conclusion.

\section{System construction and model}

\subsection{Grid-connected PV system}

The global construction of grid-connected PV system is shown in Fig. 1. The main configuration of the system is PV cells that are the power source or generator of the light energy, which are arranged in series or parallel to achieve the highest benefit of the solar radiation. Another component is DC/DC converter that is mainly controlled during the coupling of MPPT control unit [23]. This unit uses the switches as a tracker to save power at the maximum point at all operating conditions. The DC/AC three phase bridge inverter circuit that connects to a conventional step up transformer that connects to a grid [24].

\subsection{PV cell model}

The general equivalent circuit of single diode PV cell model that explains the main process of the PV cell is as shown in Fig. 2. This model is composed of numbers of silicon cells which operates as a current source, also these cells are assembled with each other in a large unit to form PV panels which are grouped in arrays [25]. In general, number of cells are used in a particular series or parallel arrangement to control the generated PV current or by change the numbers of the cells in each panel. The generated current of PV cell at a certain condition of radiation and temperature is illustrated as follows [26].

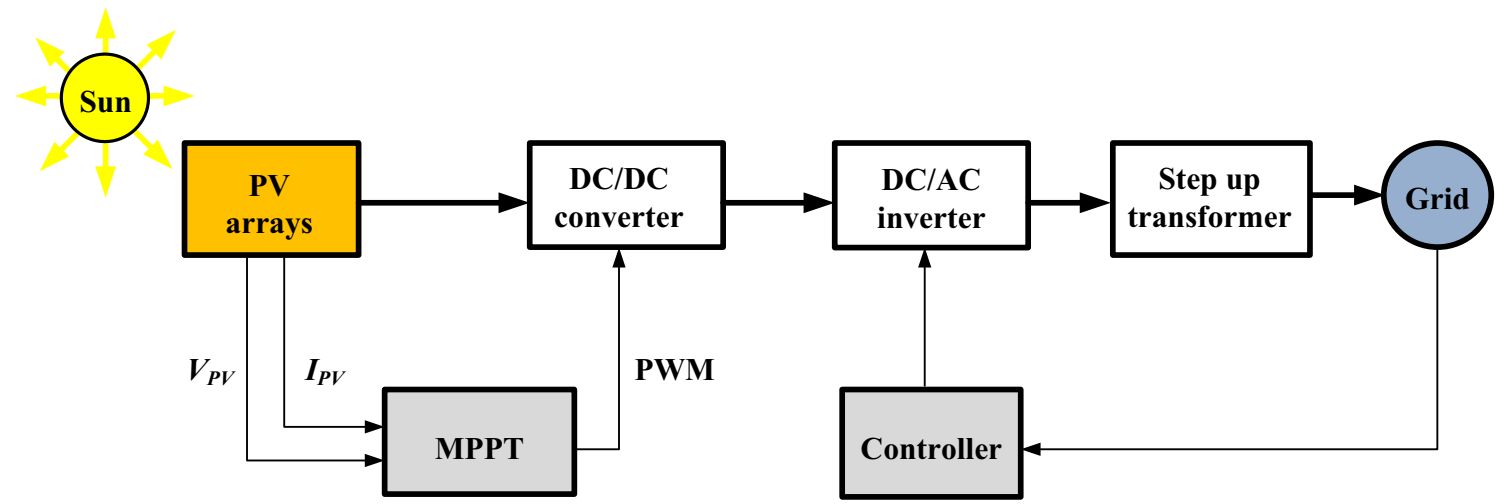

Fig. 1 Block diagram of grid-connected PV system 


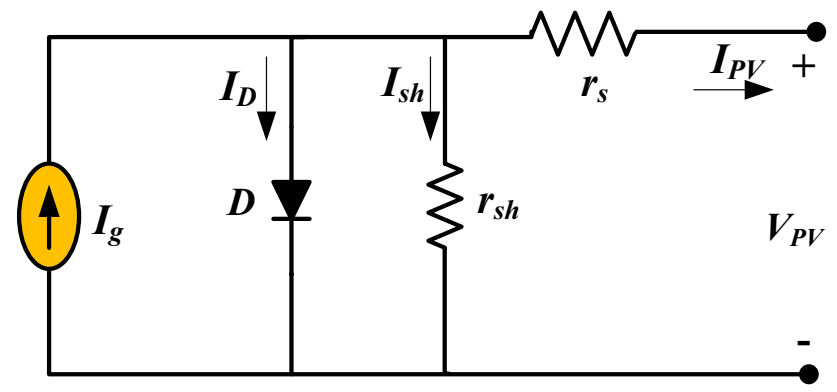

Fig. 2 Equivalent circuit of PV cell

$I_{P V}=I_{g}-I_{D}-I_{s h}$

where $I_{g}$ is the light current, $I_{D}$ is the diode current and $I_{s h}$ is the shunt resistance current.

$I_{P V}=n_{p} I_{g}-n_{P} I_{o}\left[\exp \left(\frac{q\left(V_{P V}+\frac{l_{P V} r_{s} n_{s}}{n_{p}}\right)}{n_{s} n_{c} A k T}-1\right)\right]-\frac{V_{P V}+\frac{l_{P V} r_{s} n_{s}}{n_{p}}}{\frac{r_{s h} n_{s}}{n_{p}}}$

where $I_{o}$ is the reverse saturation current of diode, $V_{P V}$ is the output voltage of PV cells, $q$ is the electron charge, $T$ is the cell temperature, $n_{p}$ are the numbers of PV modules in parallel, $n_{s}$ are the numbers of PV modules in series, $n_{c}$ are the series arranged PV cells, $k$ is the Boltzmann constant, $A$ is the ideality factor of diode and $r_{s h}, r_{s}$ are the shunt and series resistance.

\subsection{DC/DC converter}

The voltage control techniques have different kinds of converters circuits that are used for increasing or decreasing the $\mathrm{DC}$ voltage these converters can be used in PV system to modify the $D C$ voltage that is generated from $P V$ arrays [4]. One of these converters that will be used here is DC/ DC boost converter. It is used to modify the PV voltage by controlling the switching operation of a semiconductor insulated gate bipolar transistor (IGBT) through the pulse width modulation (PWM) generator from the MPPT control unit. The ratio between the switches' operation on and off time with a constant frequency is called a duty cycle. In Fig. 3 shows the main components of the boost converter circuit with the output parameters of DC current and voltage as following [27].

$V_{d c}=\frac{V_{P V}}{1-\delta}$

where $V_{d c}$ is the output voltage of the boost converter, and $\delta$ is the duty cycle.

The main two modes operation of boost converter are constructed through IGBT switch, when the switch signal $S$ is $O N$, the value of $\delta$ equals 1 at which the diode has an inverse polarity so the current will flow through inductor to store energy. Also, when switch signal $S$ is OFF, the $\delta$ value equals 0 and the diode changes its polarity, at which the magnetic field will be discharged to DC link and the induced voltage polarity will be reversed as the following [28].

$\frac{d l_{L}}{d t}=\frac{1}{L}\left(V_{P V}-R I_{L}-(1-\delta) V_{d c}\right)$

$\frac{d V_{P V}}{d t}=\frac{1}{C_{P V}}\left(I_{P V}-\frac{I_{d c}}{(1-\delta)}\right)$

$I_{d c}=I_{L}(1-\delta)$

where $C_{P V}$ is the filter capacitor $I_{d c}$ is the output current of converter circuit, $I_{L}$ is the inductor current, $R$ and $L$ are the internal resistance and inductance of the inductor.

\subsection{P\&O MPPT algorithm}

The algorithm of $\mathrm{P} \& \mathrm{O}$ is a widely used technique as a type of MPPT in power systems applications, where it is simple and easy to implementation characteristics. It explains
Fig. 3 Circuit diagram of the DC/DC boost converter

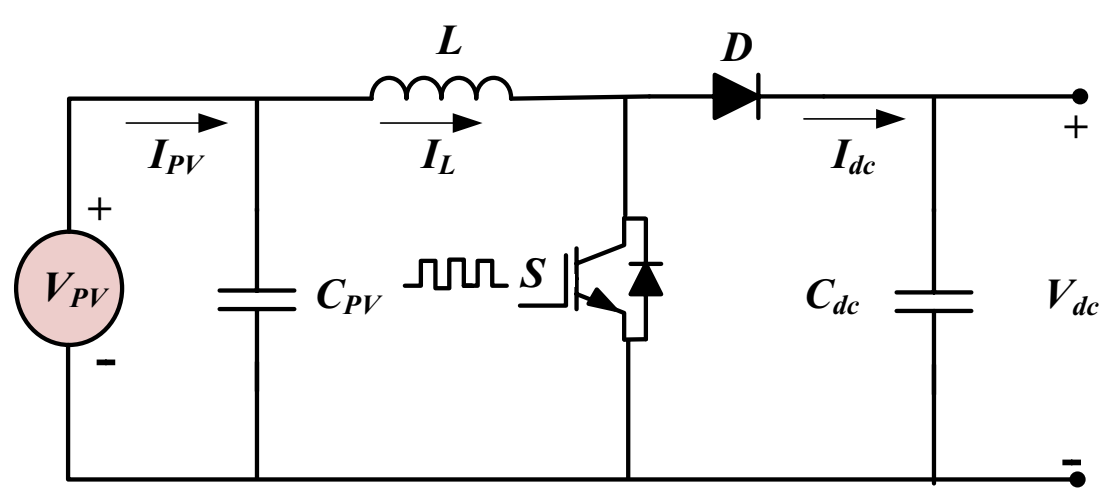


the relation between the $\mathrm{DC}$ current and voltage of $\mathrm{PV}$ in the I-V characteristic curve and uses these parameters for power tracking. On the other hands, $\mathrm{P} \& \mathrm{O}$ illustrates the relation between $D C$ power and voltage of $P V$ through the $P-V$ characteristic curve $[29,30]$. I-V and P-V characteristic curves of $\mathrm{P} \& \mathrm{O}$ method at a certain temperature $25^{\circ} \mathrm{C}$ and a certain radiation $1000 \mathrm{~W} / \mathrm{m}^{2}$ are shown in Fig. 4. The main points of I-V curve are $V_{O C}$ open circuit voltage, $I_{s c}$ is the short circuit current that has a maximum value if $V_{O C}=$ zero, $V_{M P P}$ is DC voltage at MPP and $I_{M P P}$ is the current of the MPP. In P-V curve $P_{\text {max }}$ and $V_{M P P}$ are the maximum values of output PV power and voltage at $\operatorname{MPP}[29,31]$. This tracking method mainly depends on a frequent perturbation of (increasing or decreasing) voltage or current values then compare the new measured power with the previous perturbation value. The sweeping for characteristic curve at the left side of MPP the perturbations values are $(\Delta P>0$ and $\Delta V>0)$, the power is tracked by reducing its value to reach MPP. On other hand, at the right side of MPP, the perturbations are $(\Delta P<0$ and $\Delta V>0)$, so power value is tracked by increasing its value until MPP [32]. The flowchart of $\mathrm{P} \& \mathrm{O}$ algorithm is shown in Fig. 5. First of all, $I_{P V}(n)$ and $V_{P V}(n)$ of $P V$ array are measured and multiplied to calculate the output power $P_{P V}(n)$ depending on sample time. For any change in the PV system operating condition occurs, $\mathrm{P} \& \mathrm{O}$ algorithm will compare the new measured values $I_{P V}(n-1)$ and $V_{P V}(n-1)$ and calculate perturbations values $\Delta P$ and $\Delta V$ [33]. The algorithm is programed for generating a unit of duty cycle $\delta$ to increase or decrease the change in $P_{P V}(n)$ to return to MPP. If the measured power is as same as reference value, the comparison between values will equal to zero and there is no change. At left side of $P-V$ curve $(\Delta P>0)$, if check value of $\Delta V$ has a positive value, $\delta$ will increase previous duty value. If the perturbations
Fig. 4 PV characteristic curves of P\&O MPPT technique. a V-I curve, $\mathbf{b}$ P-V curve

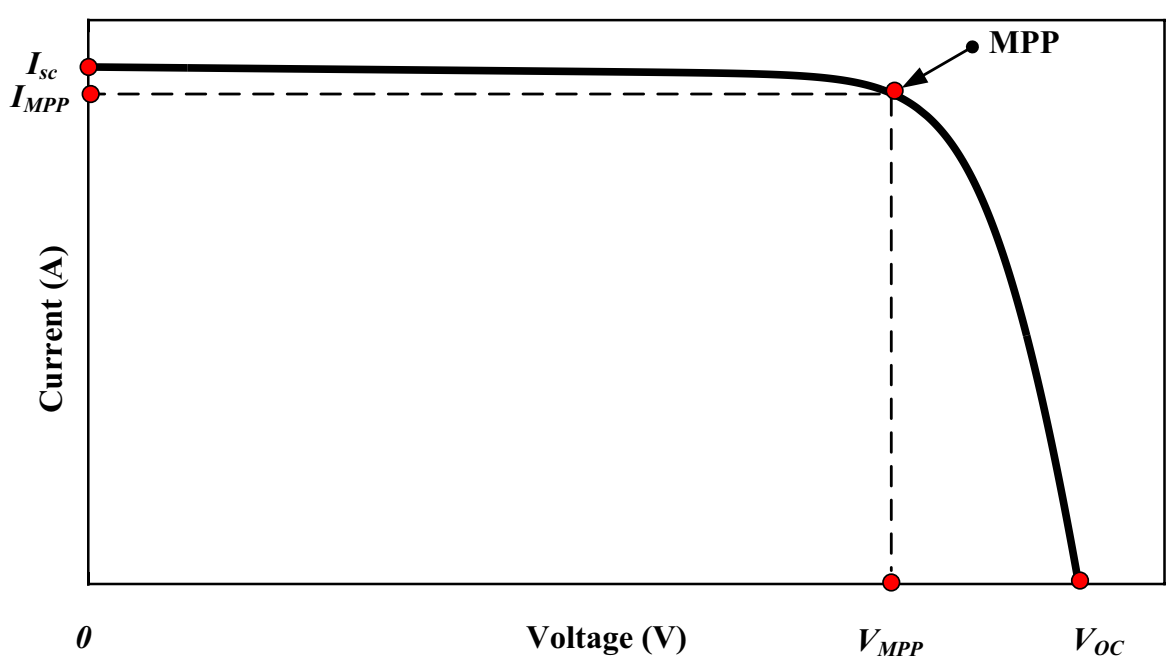

(a)

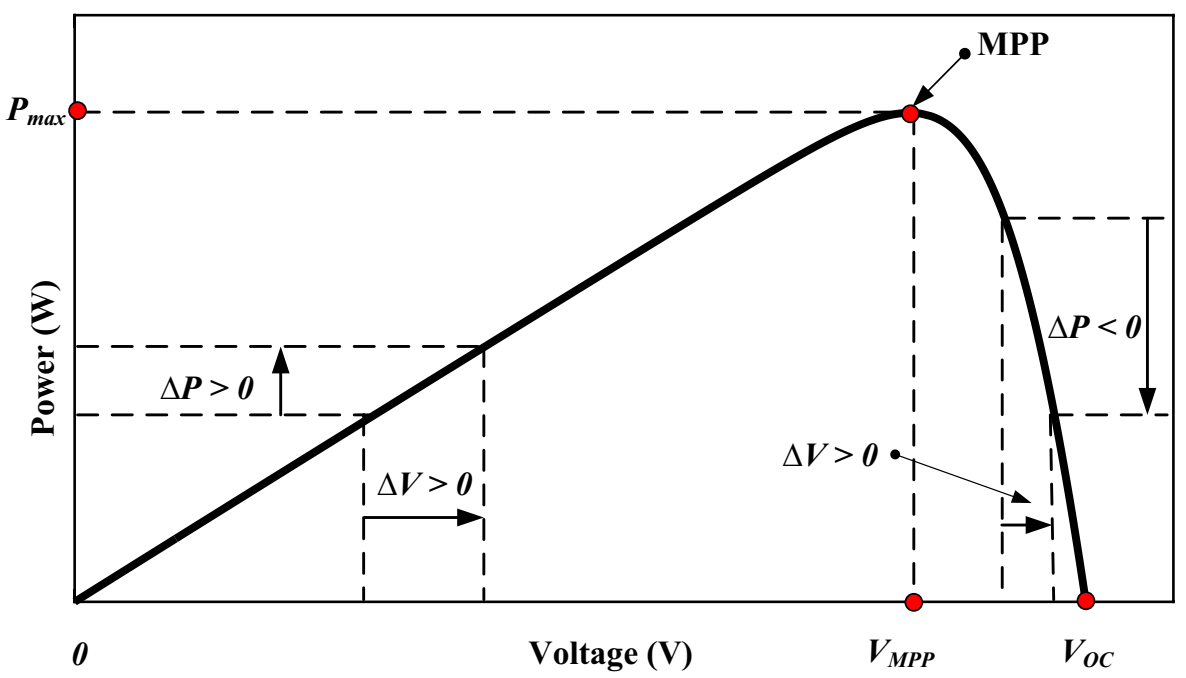

(b) 
Fig. 5 Flowchart of P\&O MPPT method

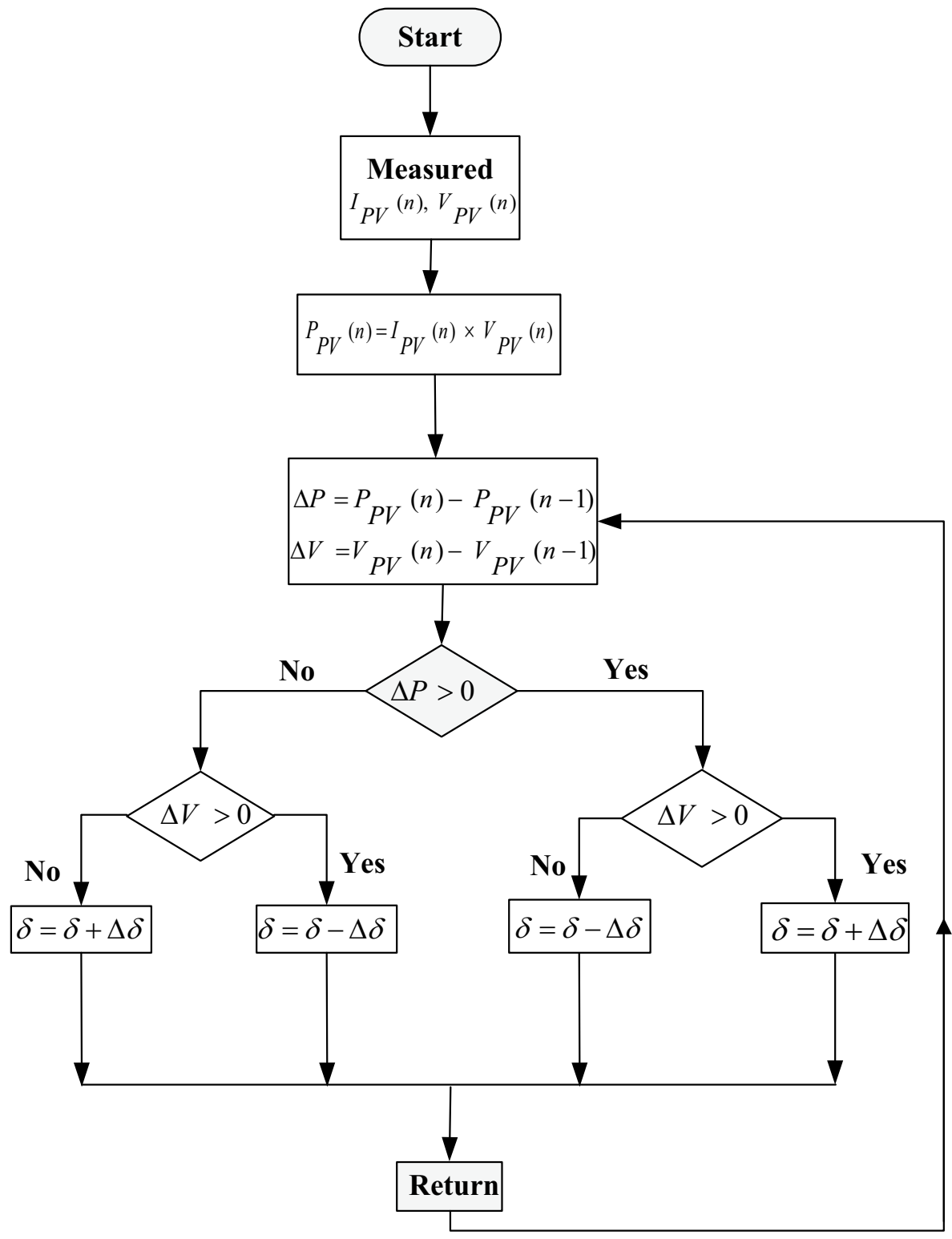

value $\Delta V$ has a negative, $\delta$ value will decrease previous calculated unit to track power to MPP. At right side of $\mathrm{P}-\mathrm{V}$ curve $(\Delta P<0)$, if $\Delta V$ has a positive value, $\delta$ will decrement previous unit, but if $\Delta V$ has a negative, $\delta$ value will increment previous calculated duty to track power again to MPP.

\subsection{DC/AC inverter}

The main function of grid side inverter is used to convert the DC power to AC power to supply AC loads and for grid integration. The electrical configuration of $D C / A C$ grid connection inverter and also, the control system of the inverter for solar PV system are illustrated in Fig. 6. The configuration circuit includes DC link capacitor, reverse current blocking diode, six semiconductor IGBTs switches, and harmonic reduction filter for grid interface. The grid side voltages $\left(V_{A}, V_{B}\right.$ and $\left.V_{C}\right)$ can be used to calculate $d-q$ grid voltages components through phase locked loop (PLL) as follows [34, 35].

$V_{d \_m}=\frac{2}{3}\left[V_{A} \sin (\beta t)+V_{B} \sin \left(\beta t-\frac{2}{3} \pi\right)+V_{C} \sin \left(\beta t+\frac{2}{3} \pi\right)\right]$

$V_{q_{-} m}=\frac{2}{3}\left[V_{A} \cos (\beta t)+V_{B} \cos \left(\beta t-\frac{2}{3} \pi\right)+V_{C} \cos \left(\beta t+\frac{2}{3} \pi\right)\right]$

where $V_{d_{-} m}$ is $d$-axis component of grid voltage, $V_{q_{-} m}$ is $q$-axis component of grid voltage and $\beta t$ is the phase angle. The first closed loop control unit of voltage controller is used to generate the reference value of $i_{d_{-} \text {ref }}$ and the reference value of $i_{q_{-} r e f}$ is equal zero or given by the 


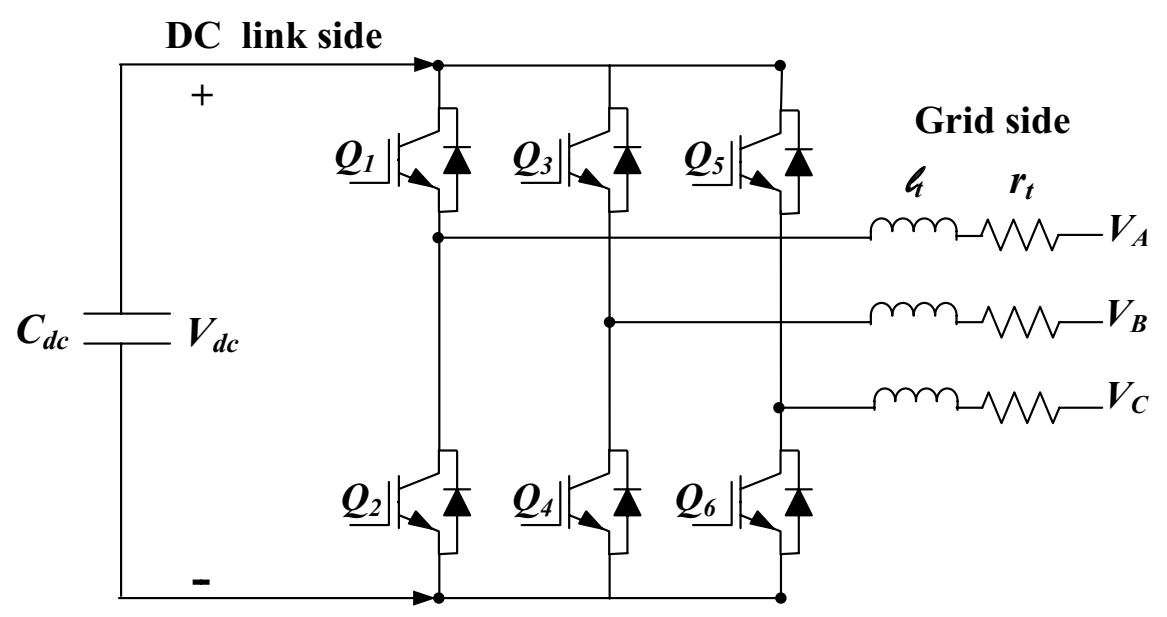

(a)

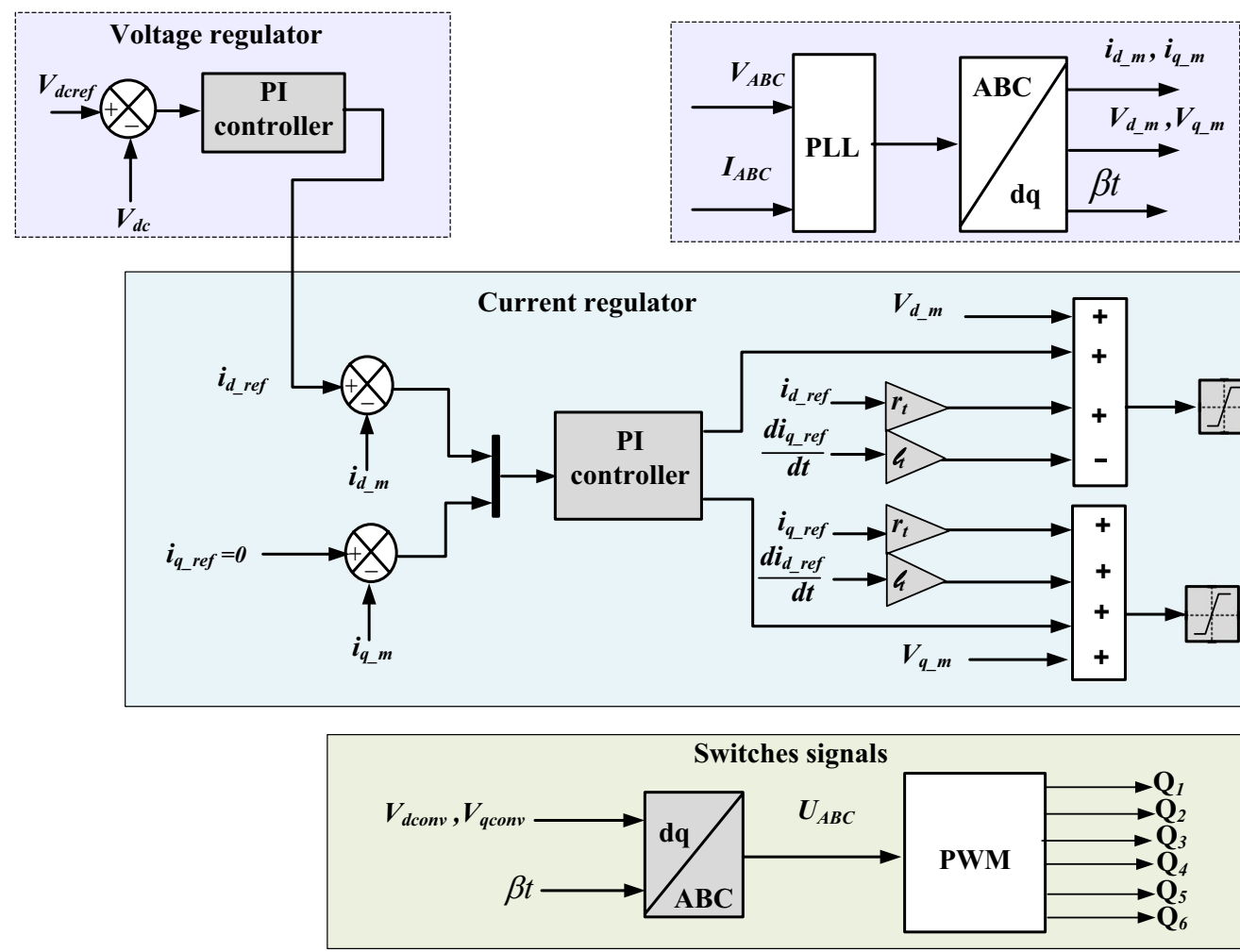

(b)

Fig. 6 Grid connection inverter with the main control system a three phase DC/AC inverter circuit. b Interface block diagram of inverter control method

operator. The voltage regulator is used to compare the DC reference voltage $V_{d c r e f}$ with measured DC voltage $V_{d c}$ to calculate the reference $d$-axis component grid current $i_{d \_ \text {ref }}$ through a proportional and integral (PI) controller as follows.

$i_{d \_r e f}=\left(V_{d c r e f}-V_{d c}\right)\left(\frac{K_{l d c}}{S}+K_{P d c}\right)$ where $K_{P d c^{\prime}} K_{I d c}$ are PI gains of voltage regulator and $i_{d \text { ref }}$ is the $d$-axis component of grid current. The second closed loop control unit of current regulator is used to compare the reference values of $d-q$ currents depending on the measured values to generate the converted $d-q$ voltages of inverter side to inject it to the terminal node this can be illustrated as follows [36]. 
$V_{d c o n v}=r_{t} i_{d_{-} r e f}-\ell_{t} \frac{d i_{q_{\_} r e f}}{d t}+V_{d_{-} m}+\left(i_{d_{-} \text {ref }}-i_{d_{-} m}\right)\left(\frac{K_{l}}{S}+K_{p}\right)$

$V_{\text {qconv }}=r_{t} i_{q_{-} \text {ref }}+\ell_{t} \frac{d i_{d_{\_} r e f}}{d t}+V_{q_{-} m}+\left(i_{q_{-} r e f}-i_{q_{-} m}\right)\left(\frac{K_{l}}{S}+K_{p}\right)$

where $V_{d c o n v}$ is $d$-axis component of inverter voltage, $V_{q c o n v}$ is $q$-axis component of inverter voltage, $i_{q}$ ref is the $q$-axis component of grid current, $i_{d \_m}$ is the measured $d$-axis current, $i_{q \_m}$ is the measured $q$-axis current, $r_{t}$ is the resistance of inverter filter, $l_{t}$ is the inductor of inverter filter and $K_{P}$, $K_{\text {l }}$ are $\mathrm{PI}$ gains of current regulator. Finally, the $\mathrm{d}-\mathrm{q}$ axis components of inverter voltage $V_{d q c o n v}$ are converted into three-phase inverter voltage $U_{A B C}$ and then, the PWM generator to generate the switching signals for IGBTs switches of the inverter.

\section{SC model and control system}

\subsection{SC model configuration}

$\mathrm{SC}$ is an ultra-capacitors type that have two plates or electrodes with ionic pores, these small pores let ions easily moving through the gap [37]. It is a technique that used to make a balance for the system energy so it considered one of important ESS type that improves the power fluctuating during any undesirable conditions. It has a lot of functions as any other ES devices known, but this one has many advantages over the other storage devices. It can be used for a long time, has a small size, has a short time for charging and discharging the energy and has a high capacity of energy storage. This ability of super storage capacitance come from its construction that has a small distance gap between the two electrodes $[9,38]$. Compared to batteries,
SC demonstrates high power performance, low maintenance, long cycle life, and easily integrated into power systems [37]. Because of SC can store more energy that makes SC technique is more applicable in high power rating engineering applications. The storage energy of SC $W_{E S S}$ can be calculated as follows.

$W_{E S S}=\int P_{S C} d t=P_{S C} t$

where $P_{S C}$ is the storage power in SC at time $t$ of grid code. The capacity size of SC is illustrated as following [18].

$W_{E S S}=\frac{1}{2} C_{S C} V_{S C}^{2}$

$C_{S C}=\frac{2 P_{S C} t}{V_{S C}^{2}}$

where $V_{S C}$ is the voltage of $S C$ and $C_{S C}$ is the capacity size of SC.

The model of SC is presented as shown in Fig. 7, where it is consists of a capacitor with parallel $R_{P}$ and series $R_{S}$ resistances. In addition to a bidirectional DC/DC converter that is presented in order to control the DC link voltage and manage the power transit between the SC and the grid. The bidirectional buck/boost converter consists of inductor and two IGBTs switches $S_{1}, S_{2}$ [39]. The model of SC with bidirectional circuit are connected in parallel with DC link side of PV, so it will have the ability to control DC voltage and this will accordingly keep the power system in balance between both PV and grid side. SC storages the extra power of system by help of the buck converter mode and it will be injected again to system at needed time. SC will be automatically connected and discharged the storage power through the boost converter mode of bidirectional circuit [40].
Fig. 7 Schematic diagram of the SC model

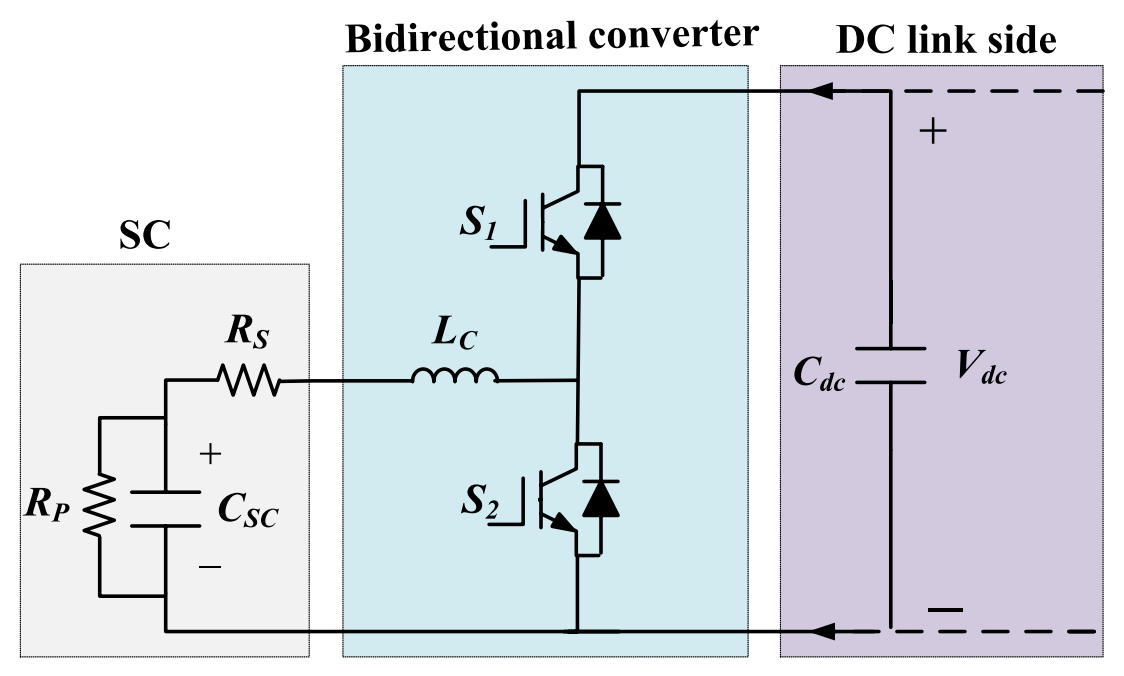




\subsection{Control principle operation modes of bidirectional converter circuit}

Figure 8 shows the control system of bidirectional buck/ boost converter circuit. It consists of two PI controllers that connect to PWM generator and NOT gate. The input controlled signals for IGBTs switches $S_{1}$ and $S_{2}$ of the converter circuit are directly from the PWM generator and NOT gate respectively.

The first PI controller is derived using two input signals to supply a reference current signal of SC by comparing the input reference and measured DC voltage signals, this is expressed as follows.

$I_{S C \text { ref }}=\left(V_{d c r e f}-V_{d c}\right)\left(K_{P_{1}}+\frac{K_{l_{1}}}{S}\right)$

where $I_{\text {SCref }}$ is the reference current of SC, $V_{d c r e f}$ is the reference DC voltage, $V_{d c}$ is the measured DC voltage and $K_{P 1}$, $K_{/ 1}$ are $\mathrm{PI}$ coefficients of the first controller. The second $\mathrm{PI}$ controller controls the current of SC through two input signals. The input signals are the generated reference and measured current signals of SC that flows in positive or negative direction according to the operating mode of converter circuit. The signals that derive IGBTs switches are directly from PWM generator to $S_{1}$ and from NOT gate to $S_{2}$ to control the operation of buck or boost mode as follows [41].

$U_{P W M}=\left(I_{S C r e f}-I_{S C}\right)\left(K_{P_{2}}+\frac{K_{I_{2}}}{S}\right)$

where $I_{S C}$ is the measured current of $S C, U_{P W M}$ is the control signal and $K_{P 2}, K_{12}$ are the PI coefficients of the second controller. The operations modes of bidirectional circuit are shown in Fig. 9. It can operate as a buck or a boost circuit where it can keep the DC voltage of PV at a constant value by storage the excess energy between PV and grid side for any condition occurs in grid side as follows [18]. If both $P_{d c}$ and $P_{\text {grid }}$ are in balance, $\mathrm{SC}$ will not have a chance to store power. If there is an unbalance between $P_{d c}$ and $P_{\text {grid }}$ SC will storage the excess power and inject it back to system to consume power at dip condition. The storage power of $\mathrm{SC}$ is defined as follows.

$P_{S C}=P_{d c}-P_{\text {grid }}$

where $P_{d c}$ is DC power of $\mathrm{PV}$ and $P_{\text {grid }}$ is the grid power. If any condition effect $D C$ voltage of $P V$, the converter circuit will operate as a buck circuit because of the DC voltage is not as the reference value. The current passes through the inductor in active direction to charge SC by the extra power system. The controlled output pulses of PWM generator will close the switch $S_{1}$ and open the switch $S_{2}$ as shown in Fig. 9a. The discharge mode of SC will achieve the power balance between the grid and PV side. SC will control the DC voltage to be as possible as reference value. So, the converter circuit operates in boost mode and the current will pass from the $\mathrm{SC}$ in a passive direction through the inductor to discharge the storage power in DC link side to compensation the leakage in power system. So, the controlled pulses of PWM generator opens the switch $S_{2}$ and close the switch $S_{1}$ as shown in Fig. 9b $[36,42]$.

\section{Egyptian FRT grid code requirements}

The grid code connection of solar energy is an important issue when a new solar system is established in any country. Each grid system must be strong for a specific duration of the voltage dips ranging up to $0 \%$ of voltage dip\%. Here, the Egyptian grid code is used with the studied solar PV system for supporting the electrical grid during faults. Figure 10 presents the Egyptian FRT grid code connection requirements for solar PV system. This grid code states that, the minimum duration time is

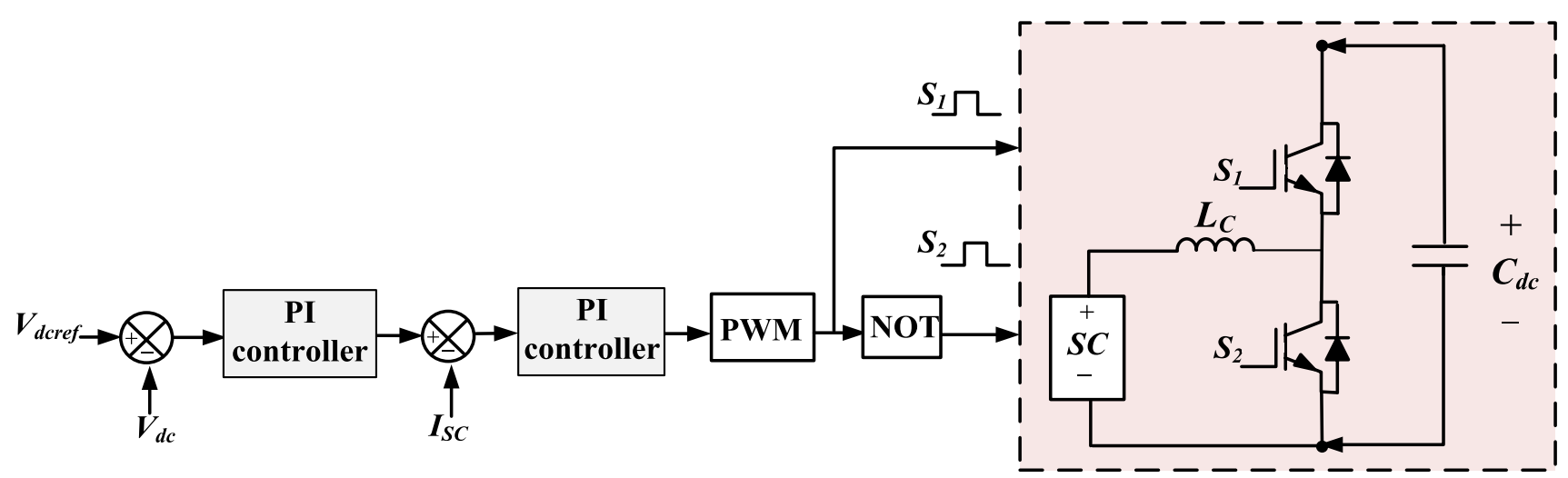

Fig. 8 Control schemes of the bidirectional converter circuit 


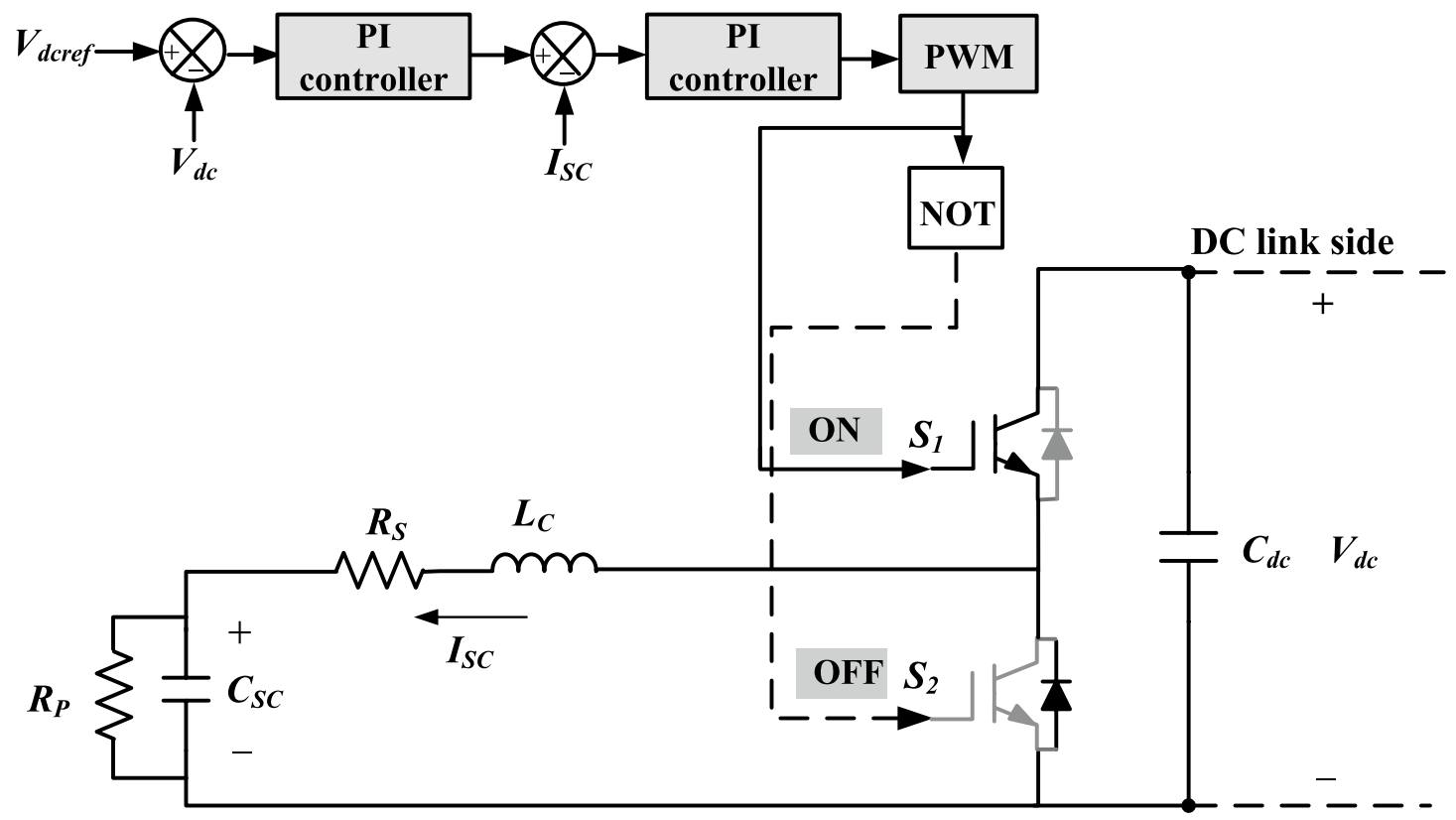

(a)

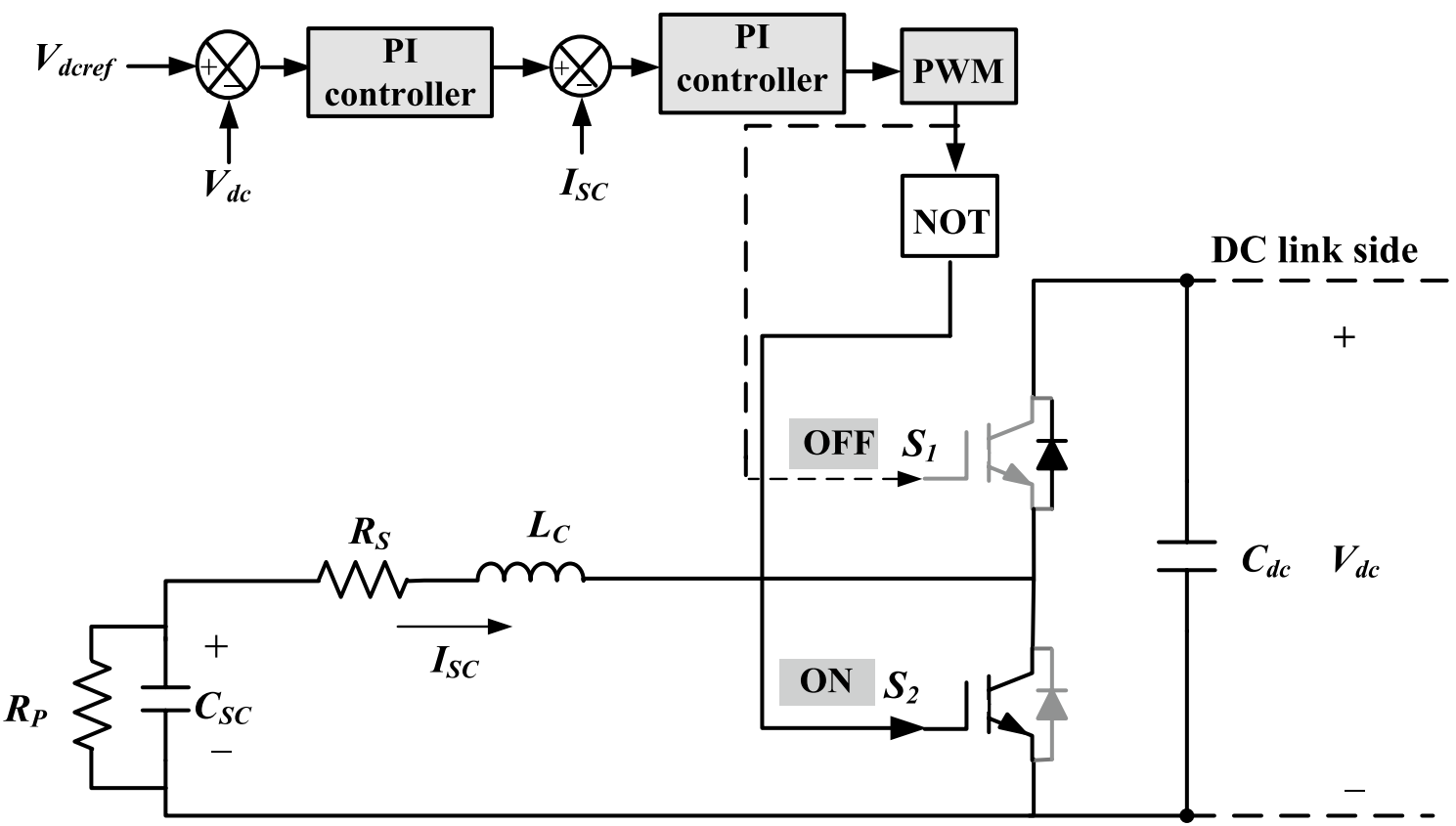

(b)

Fig. 9 Control operating modes of bidirectional converter: a SC charging mode. b SC discharging mode

equal to or less than $250 \mathrm{~ms}$, and the maximum duration time to restore the voltage is equal to $10 \mathrm{~s}$. The grid code is not allowed to disconnect the PV system from the grid during voltage drops above the curve as shown in Fig. 10 [43]. Also, the PV system shall be tripped if only the voltage level value is below the area of FRT curve.

\section{Studied grid-connected PV system}

The case study model of the grid-connected PV system with a parallel connection of SC model is as shown in Fig. 11. The PV array is consisted of four panel each one 
Fig. 10 Egyptian FRT profile curve of PV system

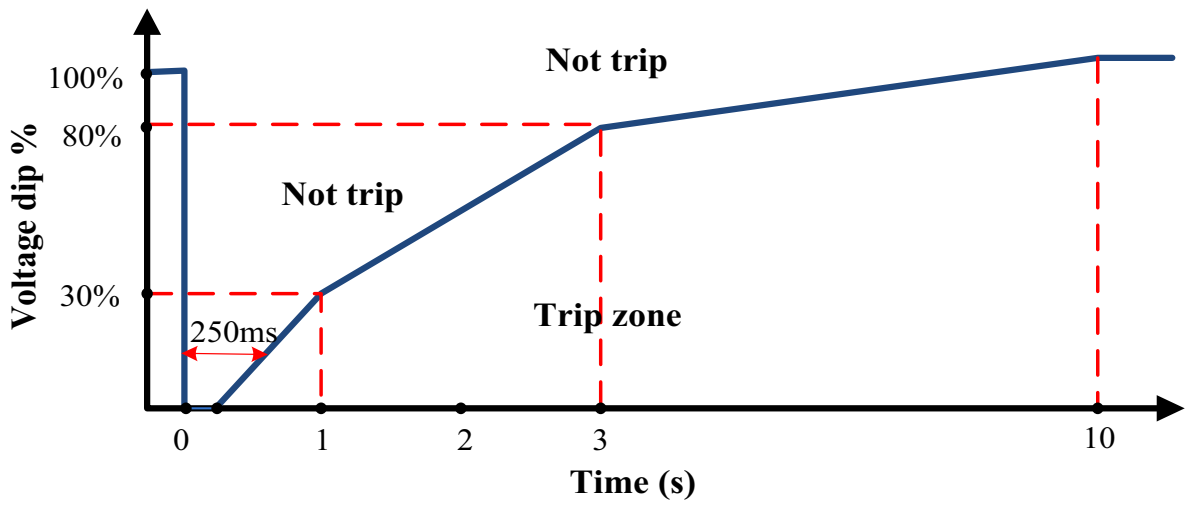

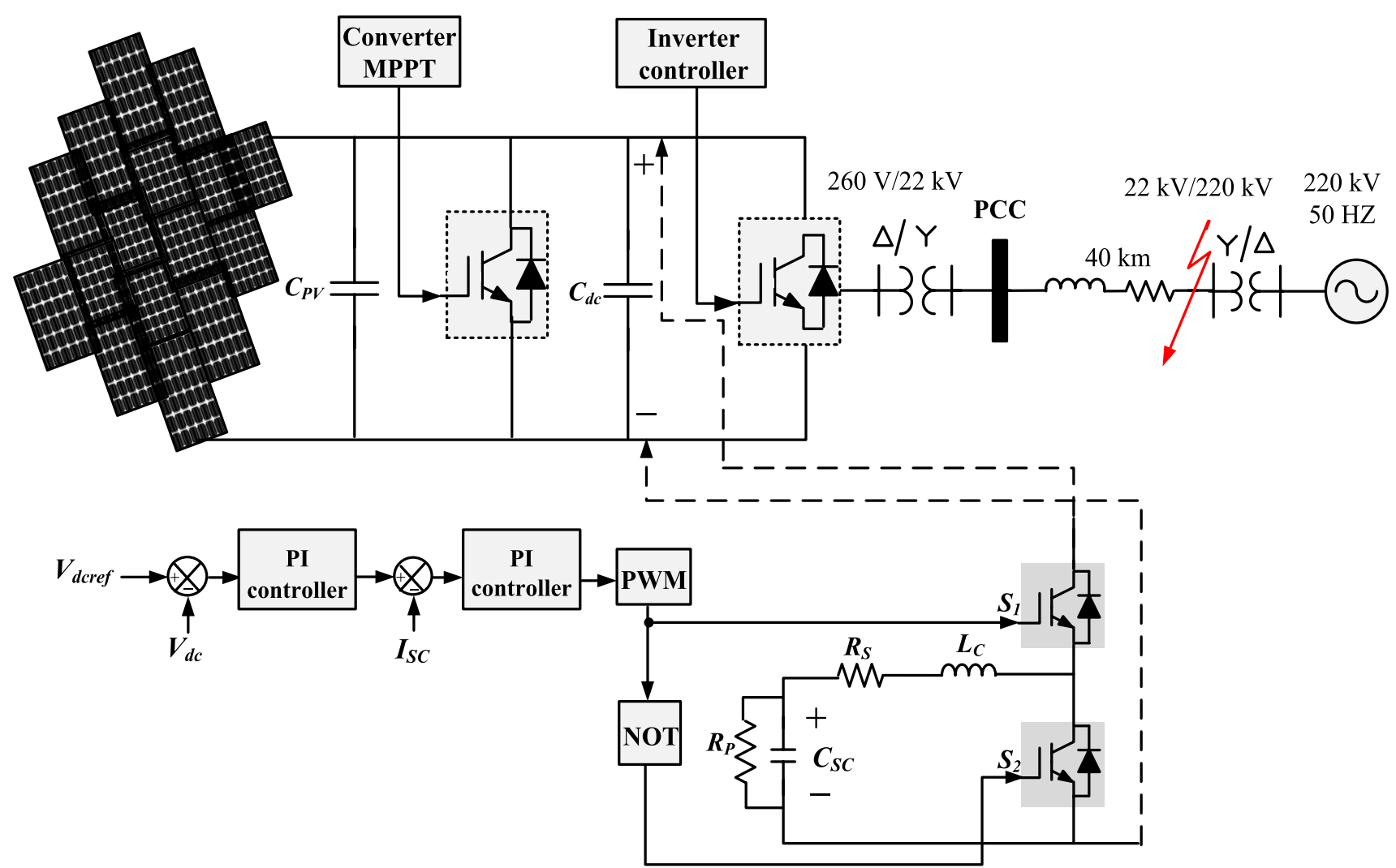

Fig. 11 Studied system configuration

has a boost converter with rated power $100 \mathrm{~kW}$ and the rated real power and DC voltage of PV array are $(400 \mathrm{~kW} / 500 \mathrm{~V})$ and connected with grid side through a $40 \mathrm{~km}$ transmission line, the rated $\mathrm{AC}$ voltage and frequency of grid side are $(220 \mathrm{kV} / 50 \mathrm{~Hz})$. The PV arrays connect to a DC/DC boost converter circuit with $\mathrm{P} \& O$ technique of MPPT control unit with a direct connection to a DC/AC inverter circuit. Also with a group of transformers which are used on the way of grid power flow. The first group is step down (delta/star) transformer with the rated voltage $(260 \mathrm{~V} / 22 \mathrm{kV})$ near the inverter side and the other group is step up (star/delta) transformer $(22 \mathrm{kV} / 220 \mathrm{kV})$ near the grid side. SC model with the main components of control unit and the bidirectional buck/boost converter circuit are connected in parallel with the capacitor of DC link side. The parameters used for the studied PV system are tabulated in Table 1. 
Table 1 Studied system parameters

\begin{tabular}{lllll}
\hline Descriptions & Parameters & Symbols & Values & Units \\
\hline PV side & Rated power & $P_{p V}$ & 400 & $\mathrm{~kW}$ \\
DC/DC boost converter & Inductance & $L$ & $5 \mathrm{e}^{-3}$ & $\mathrm{H}$ \\
& Resistance & $R$ & $5 \mathrm{e}^{-3}$ & $\Omega$ \\
& Filter capacitor & $C_{P V}$ & $100 \mathrm{e}^{-6}$ & $\mathrm{~F}$ \\
DC link side & Rated voltage & $V_{d c}$ & 500 & $\mathrm{~V}$ \\
& Capacitance of DC link side capacitor & $C_{d c}$ & $50 \mathrm{e}^{-3}$ & $\mathrm{~F}$ \\
SC model & Capacitance of SC & $C_{S C}$ & 20 & $\mathrm{~F}$ \\
& Series resistance & $R_{S}$ & $100 \mathrm{e}^{-3}$ & $\Omega$ \\
& Parallel resistance & $R_{P}$ & $122 \mathrm{e}^{-3}$ & $\Omega$ \\
DC/DC bidirectional converter & Inductance & $L_{C}$ & $10 \mathrm{e}^{-3}$ & $\mathrm{H}$ \\
& Controller proportional coefficients & $K_{P 1}, K_{P 2}$ & 350 & - \\
& Controller integral coefficients & $K_{l 1}, K_{12}$ & 250 & - \\
DC/AC inverter & Voltage regulator PI coefficients & {$\left[K_{P d c^{\prime}} K_{l d c}\right]$} & {$[7,800]$} & - \\
& Current regulator PI coefficients & {$\left[K_{p,} K_{l}\right]$} & {$[0.3,20]$} & - \\
& Resistance of filter & $r_{t}$ & $1 \mathrm{e}^{-3}$ & $\Omega$ \\
& Inductor of filter & $\ell_{t}$ & $45 \mathrm{e}^{-6}$ & $\mathrm{H}$ \\
Grid side & Rated voltage & $V_{g r i d}$ & 220 & $\mathrm{kV}$ \\
& Rated frequency & $f$ & 50 & $\mathrm{~Hz}$ \\
\hline
\end{tabular}

\section{Simulation results}

To validate of the proposed methodology of the studied PV system performance equipped with the SC model, the different conditions of faults types are investigated. The simulation studies are done in MATLAB/Simulink software. The system is tested under different fault types for a time period of $250 \mathrm{~ms}$ as shown in Fig. 11. The different faults types occur near grid side are single line to ground (SLG), double line to ground (DLG), three line to ground (TLG) faults and voltage dip. Each fault analysis is performed in grid-connected PV system to analyze the behavior of the studied system in cases of without and with SC model.

\subsection{Effect of SLG fault}

In case of studying the SLG fault that is applied at grid side for a time that varies from 7 to $7.25 \mathrm{~s}$. The impact of fault on the performance of DC voltage is shown in Fig. 12a. In case of without SC, it fluctuate between 600 and $430 \mathrm{~V}$ then after the fault time it oscillates between 670 and $430 \mathrm{~V}$ before returning to normal $500 \mathrm{~V}$. However with SC, the DC voltage fluctuates between 510 and $470 \mathrm{~V}$ but, it stabilizes at rated value after fault time. The active power is illustrated in Fig. 12b, without SC it oscillates between 490 and $300 \mathrm{~kW}$, also these oscillation still at the clearance time between 450 and $50 \mathrm{~kW}$ before it stabilizes at rated $378 \mathrm{~kW}$. Otherwise with SC, active power at fault time is oscillated between 400 and $350 \mathrm{~kW}$ but, it returns to rated value after fault. The reactive power shown in Fig. 12c, without SC the disturbance is varied between 30 and
$-20 \mathrm{kVAR}$, and it fluctuates between 160 and $-160 \mathrm{kVAR}$ at clearance time. With SC, the fluctuations are between 10 and $-20 \mathrm{kVAR}$ but, it stabilize at zero after fault.

\subsection{Effect of DLG fault}

In this subsection, the behavior of PV system during a DLG fault with and without $\mathrm{SC}$ is investigated in Fig. 13. DC voltage without SC fluctuates between 750 and $430 \mathrm{~V}$, also at fault clearance time, it fluctuates between 430 and $750 \mathrm{~V}$ before it returns again to rated value $500 \mathrm{~V}$. The impact of $\mathrm{SC}$, the DC voltage changes between 510 and $484 \mathrm{~V}$ then after fault time, voltage stabilizes at the value of $500 \mathrm{~V}$ as shown Fig. 13a. The performance of active power is shown in Fig. 13b without SC, the power oscillates between 420 and $50 \mathrm{~kW}$, also after fault time it oscillates between 300 and $-50 \mathrm{~kW}$. On other side with SC, the value decreases to $50 \mathrm{~kW}$ then after fault the power stabilizes at rated value. The reactive power behavior is shown at fault time in Fig. 13c, without SC it has a disturbance from 120 to -120 kVAR and at fault clearance it oscillates between 200 and -200 kVAR. While that, with SC it oscillates between 50 and -150 kVAR then stabilizes at zero after fault clearance time.

\subsection{Effect of TLG fault}

The impact of TLG fault on system parameters during with and without SC is investigated in Fig. 14. DC voltage performance is shown in Fig. 14a, without SC it fluctuates between 780 and $430 \mathrm{~V}$. After fault time it fluctuates 


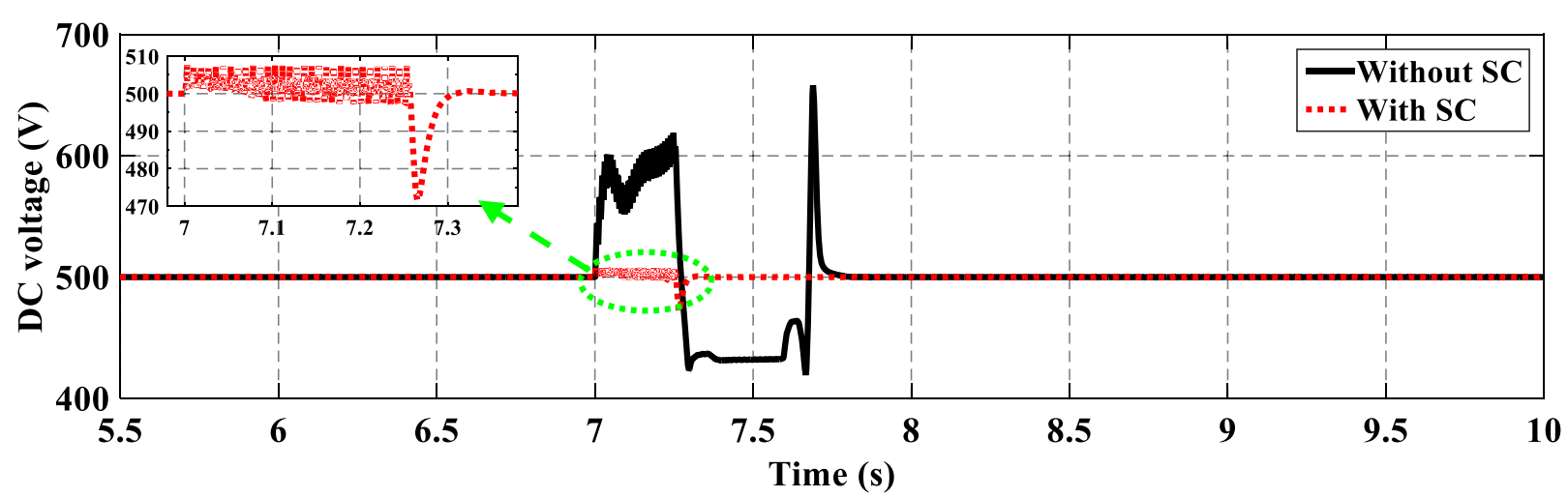

(a)

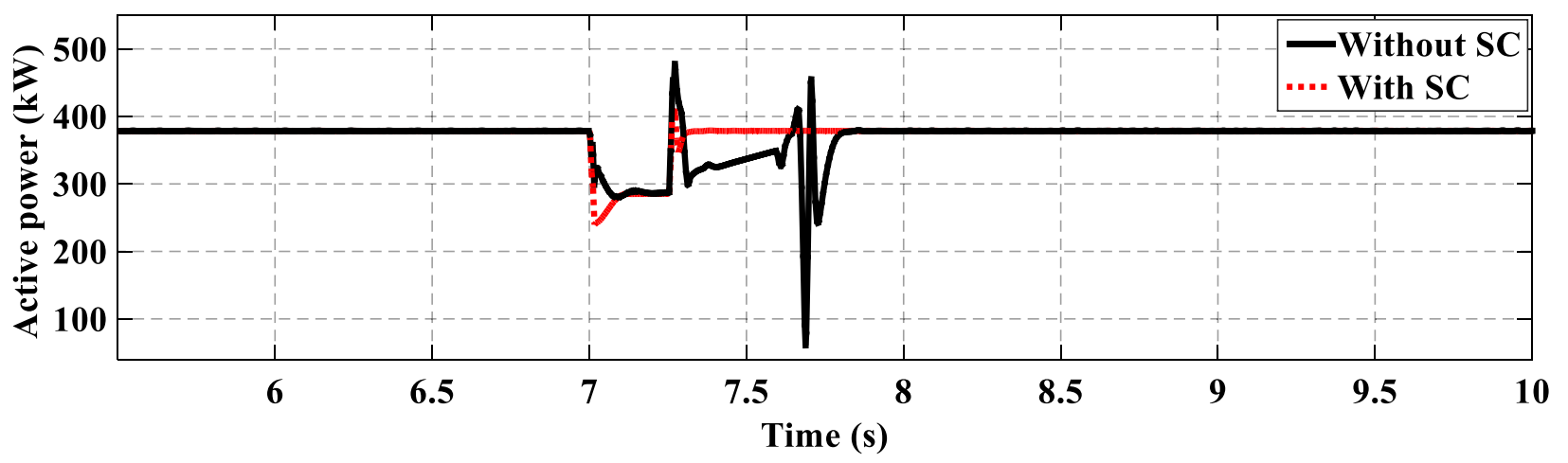

(b)

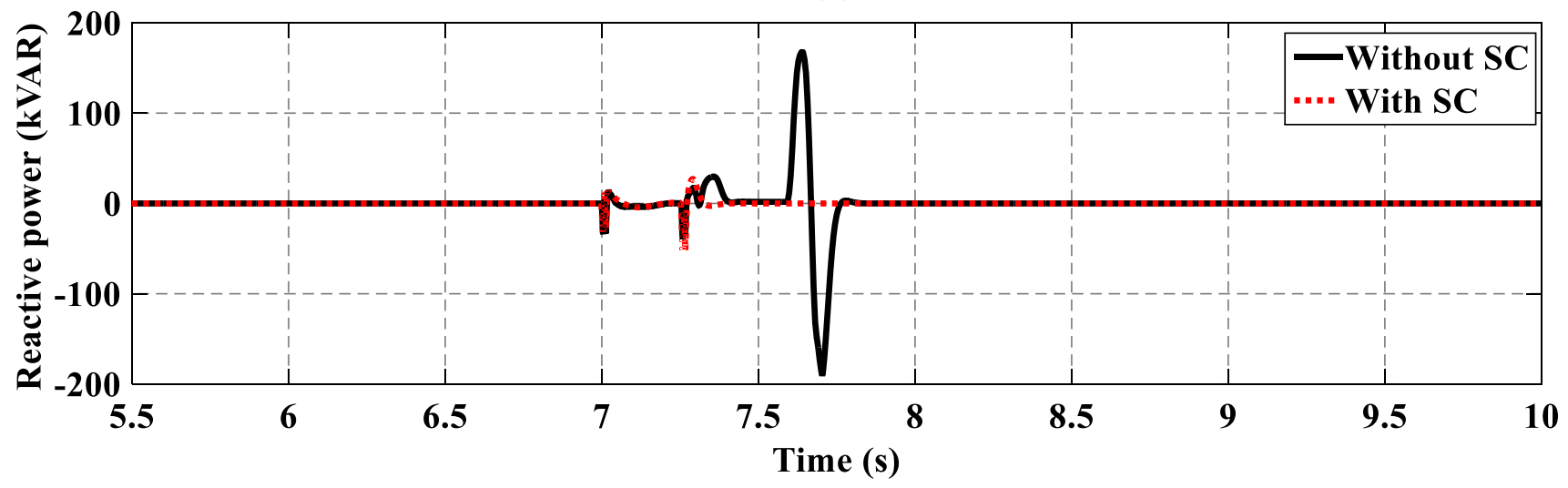

(c)

Fig. 12 Variations of system parameters during SLG: a DC voltage. b Active power. c Reactive power

between 430 and $750 \mathrm{~V}$ before it returns to the rated voltage. In addition with SC, the DC voltage fluctuates between 510 and $490 \mathrm{~V}$ then the voltage stabilizes at rated of $500 \mathrm{~V}$. The active power is shown in Fig. 14b, without SC the power decreases to zero but, after the fault time it fluctuates between 400 and $-100 \mathrm{~kW}$. On the other hand with SC, the value decreases to zero then after fault time it stabilizes at the rated of $378 \mathrm{~kW}$. The behavior of the reactive power is shown in Fig. 14c, without SC it has a disturbance from 250 to $-370 \mathrm{kVAR}$. Also, at clearance time, it oscillates between 150 and -150 kVAR. While with SC connection, it oscillates between 100 and $-350 \mathrm{kVAR}$ then return to zero after fault clearance.

\subsection{Effect of voltage dip}

In this case studied the impact of $50 \%$ voltage dip that is applied at grid side. DC voltage action is shown in Fig. 15a, without SC it fluctuates between 600 and $430 \mathrm{~V}$, then at fault clearance time it oscillates between 650 and $430 \mathrm{~V}$ before returning to normal value. Also the fluctuations with SC are between the normal value 


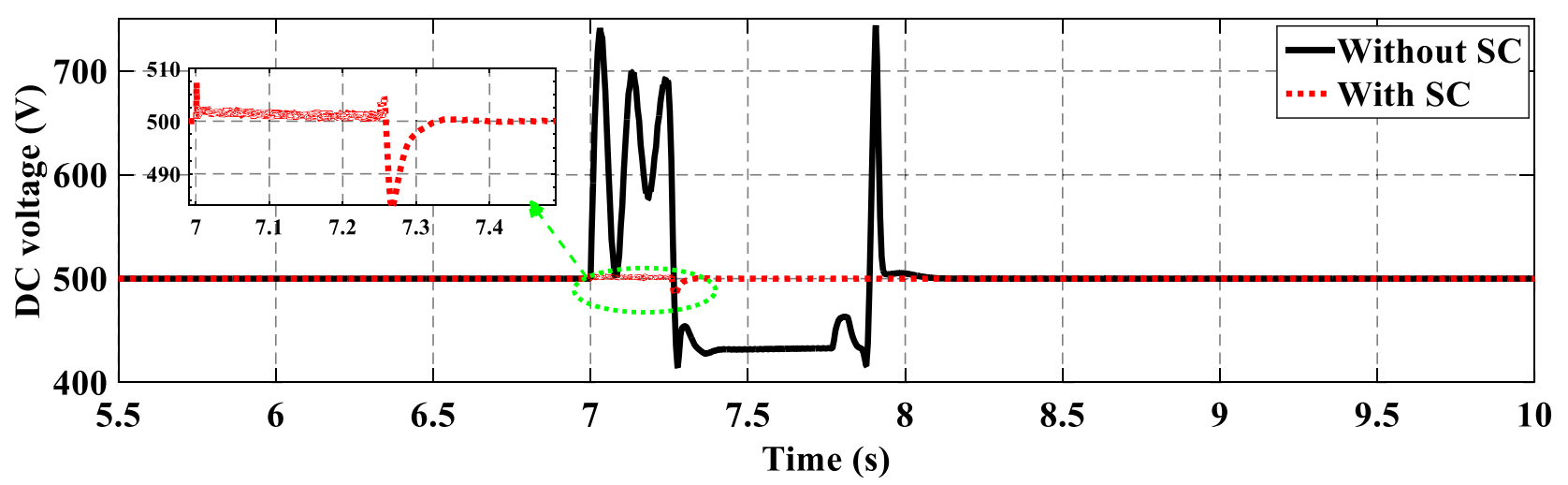

(a)

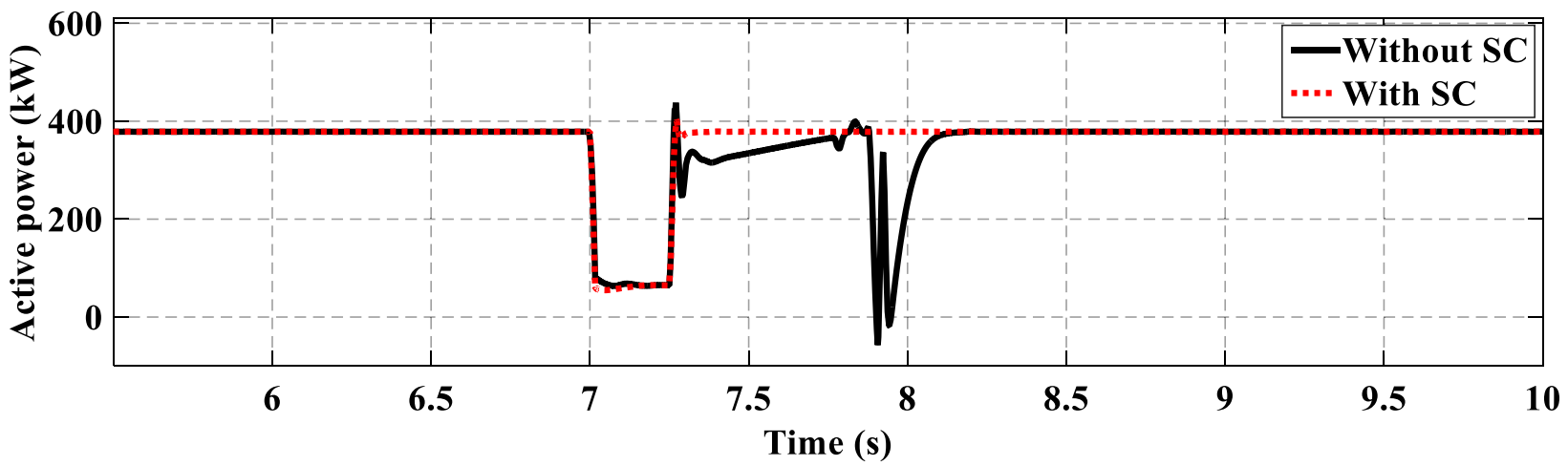

(b)

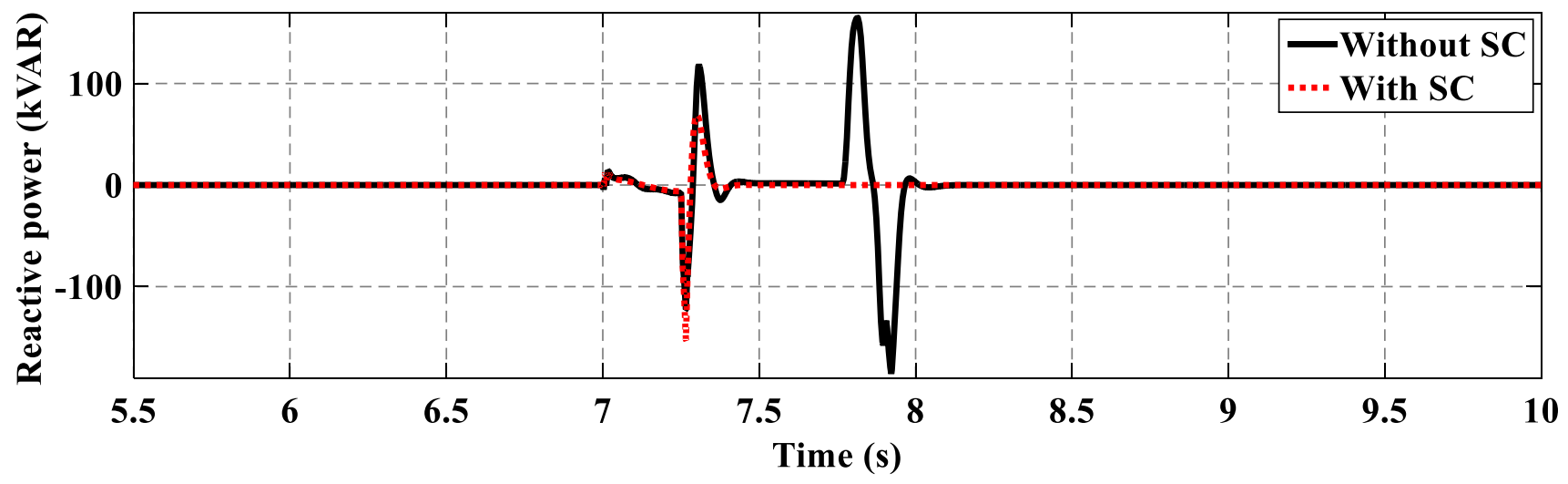

(c)

Fig. 13 Variations of system parameters during DLG: a DC voltage. b Active power. c Reactive power

of $500 \mathrm{~V}$ and $460 \mathrm{~V}$ but when fault is cleared, it stabilizes at normal value of $500 \mathrm{~V}$. The active power is shown in Fig. 15b, without SC the oscillations are between 280 and $500 \mathrm{~kW}$. At the clearance time, oscillations are between 500 and $50 \mathrm{~kW}$ before it stabilizes at $378 \mathrm{~kW}$. Also, with SC it oscillates between 410 and $250 \mathrm{~kW}$ then returns to rated value. The reactive power is shown in Fig. $15 \mathrm{c}$, without SC it has a disturbance from 0 to $30 \mathrm{kVAR}$, also it oscillates between 160 and - 200 kVAR at fault clearance period. On the other hand with SC, the oscillations changes between 0 and 5 kVAR but, it stabilizes at zero value after fault time.

Also, in case of applied $75 \%$ voltage dip at grid side the impacts are shown in Fig. 16. DC voltage behavior is shown in Fig. 16a without SC, it fluctuates between 700 and $430 \mathrm{~V}$. Also, at fault clearance time these oscillations continue for a time before returning to rated value. The impacts of SC connection, it fluctuates between 510 and $475 \mathrm{~V}$ but, at fault clearance it stabilizes at normal of $500 \mathrm{~V}$. The active power is shown in Fig. 16b, without 


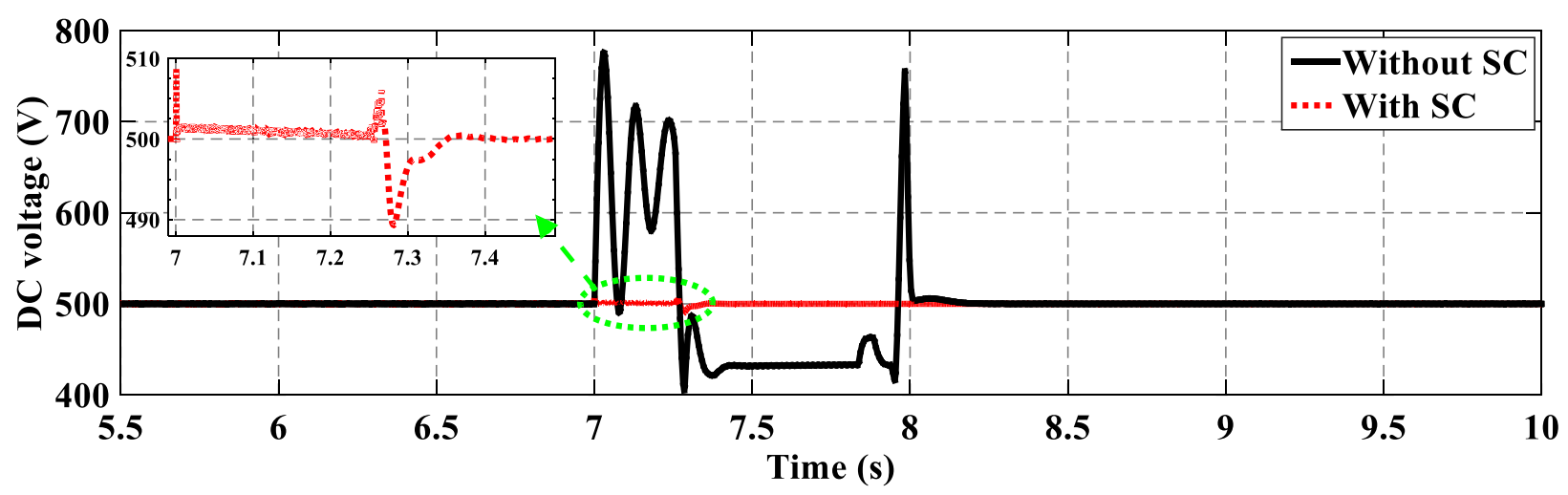

(a)

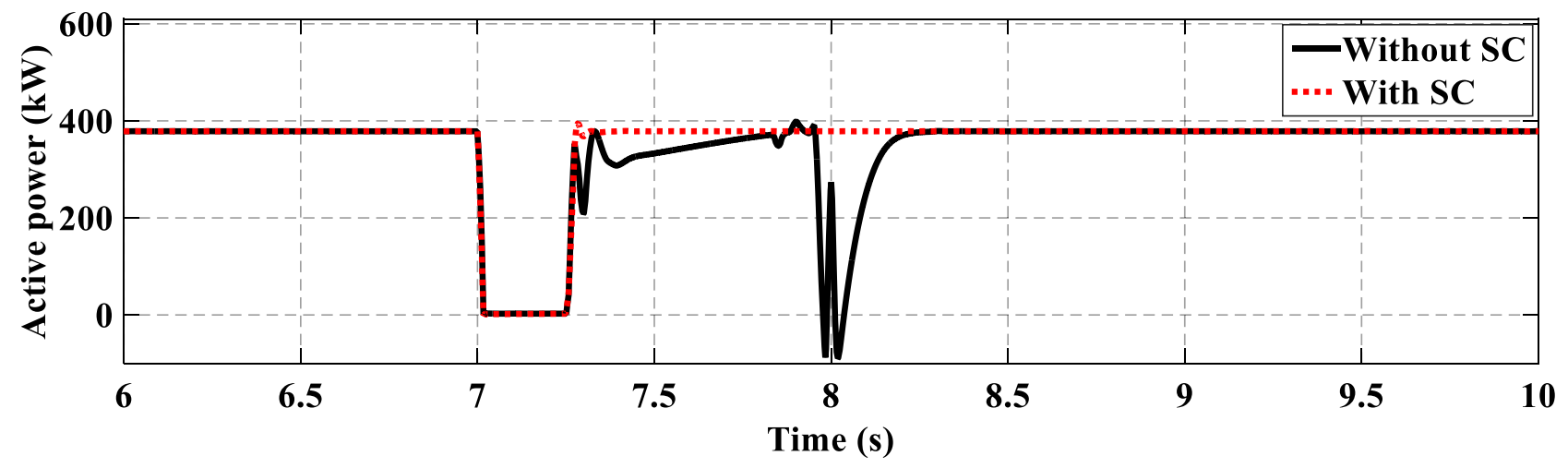

(b)

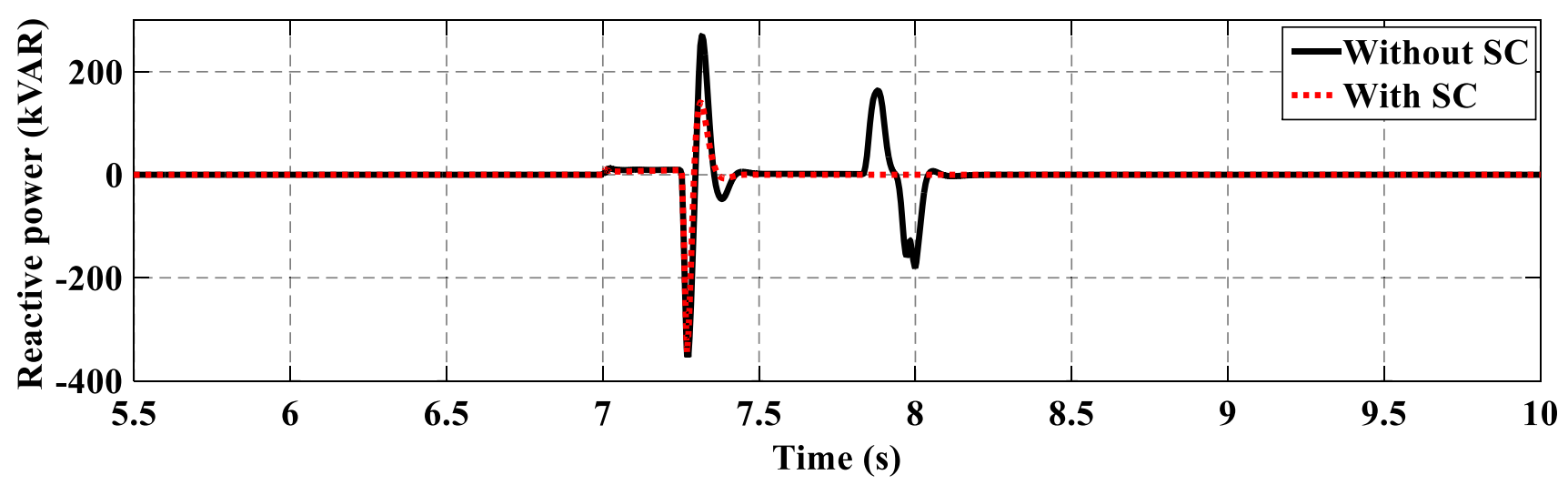

(c)

Fig. 14 Variations of system parameters during TLG: a DC voltage. b Active power. c Reactive power

SC the oscillation is varied between 490 and $120 \mathrm{~kW}$. At the clearance time this oscillation is between 450 and $0 \mathrm{~kW}$ value before it stabilizes at $378 \mathrm{~kW}$. Also with SC, it reduces to $120 \mathrm{~kW}$ then returns immediately to rated value. The reactive power is shown in Fig. 16c, without SC it has a disturbance between 50 and 0 kVAR and it oscillates between 160 and - 160 kVAR at fault clearance. At the connection time of SC, the oscillation changes only between 20 and $-5 \mathrm{kVAR}$, but it quickly stabilizes at zero.

\section{Conclusion}

This paper studies the stability improvement of $400 \mathrm{~kW}$ grid-connected PV system during faults. The simulated of system is equipped with an ESS strategy to present a solution for reducing the fluctuations of system parameters. The investigation of the stability system parameters as DC voltage, active and reactive power using 


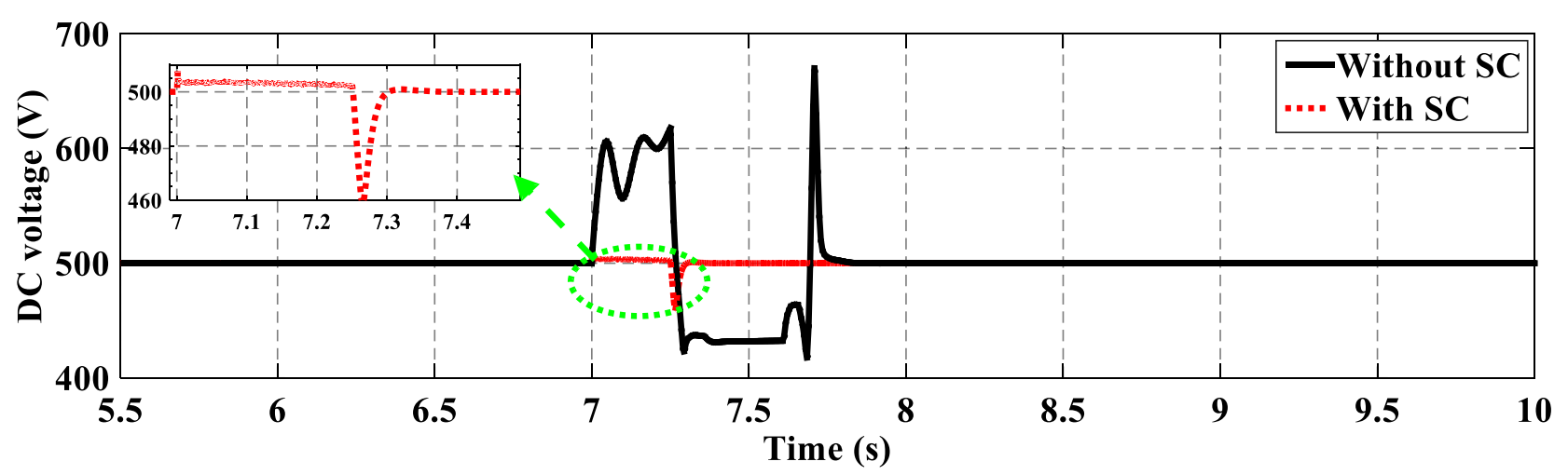

(a)

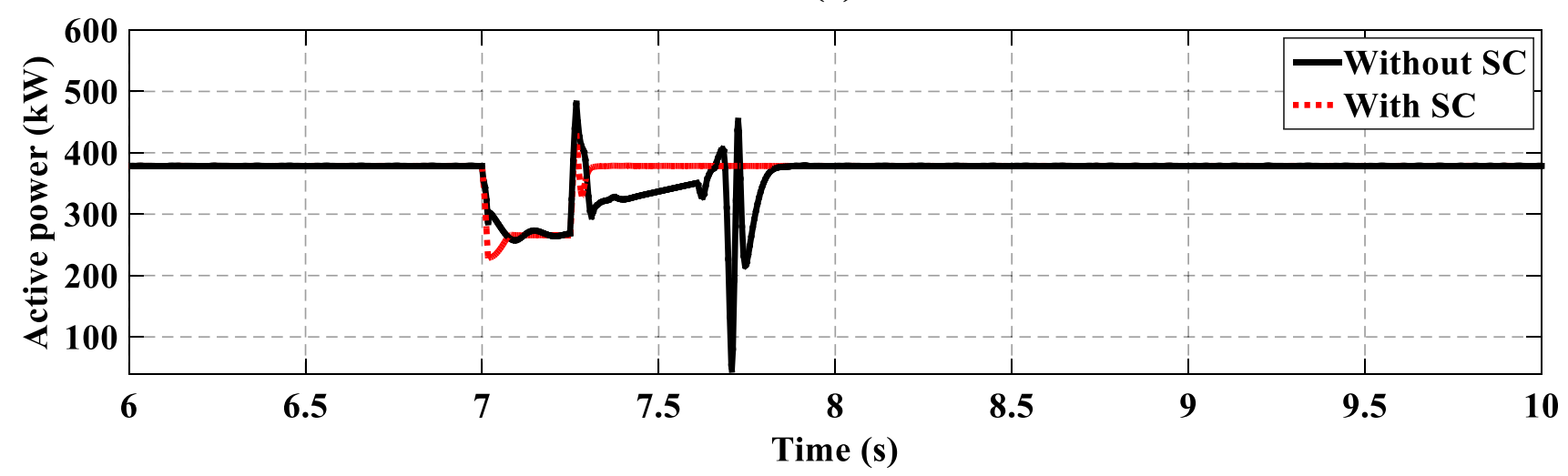

(b)

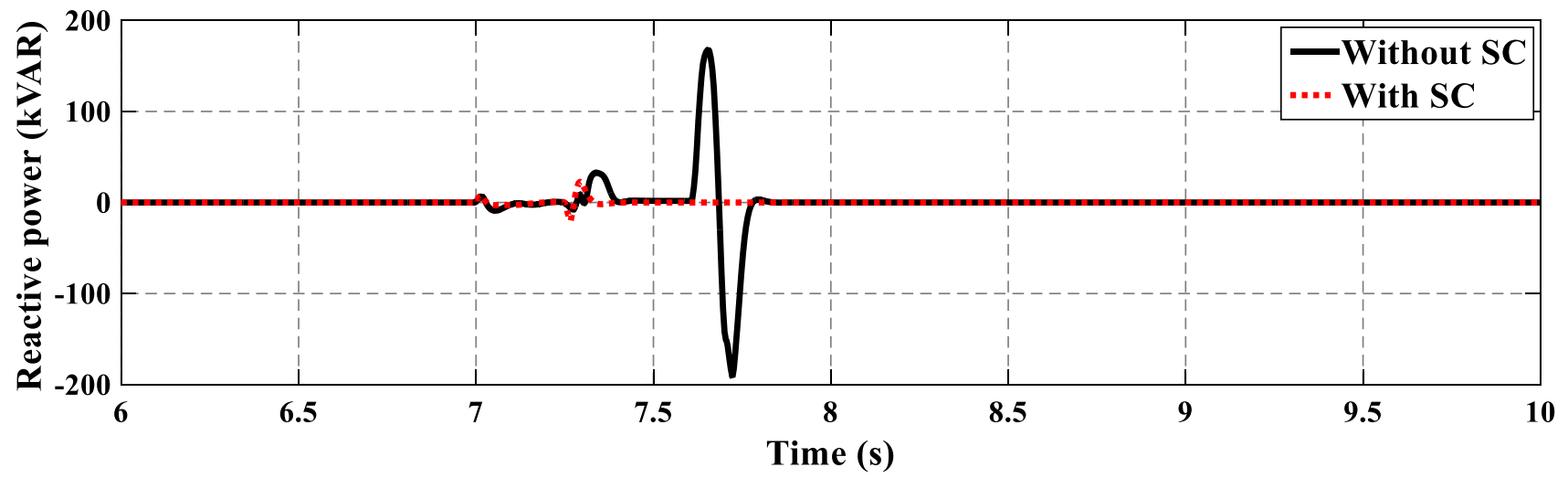

(c)

Fig. 15 Variations of system parameters during 50\% voltage dip: a DC voltage. b Active power. c Reactive power

SC is studied. SC technique is mainly used to keep the value of DC voltage at its maximum value accordingly saves power balance between the generating and the absorbing side. The SC model consists of an ultra-capacitor with a parallel resistance in connecting to a series one. A bidirectional buck/boost converter circuit with two IGBTs switches with a smoothing inductor, which sets the operating mode of SC to charge or discharge the extra power of system. The SC is connected in parallel with the capacitor of DC link side. The impact of SC on system is studied under different types of the grid faults. SC can control DC voltage of PV side at a constant value during faults by charging power through a buck mode of the converter, and then it discharges through a boost mode. The results of system parameters with SC shows an improvement in the system stability during the applied of faults. The impacts of SLG, DLG, TLG and voltage dip faults in cases of with and without SC are studied for a period of $250 \mathrm{~ms}$ based on Egyptian grid code. A comparison with or without the SC technique is 


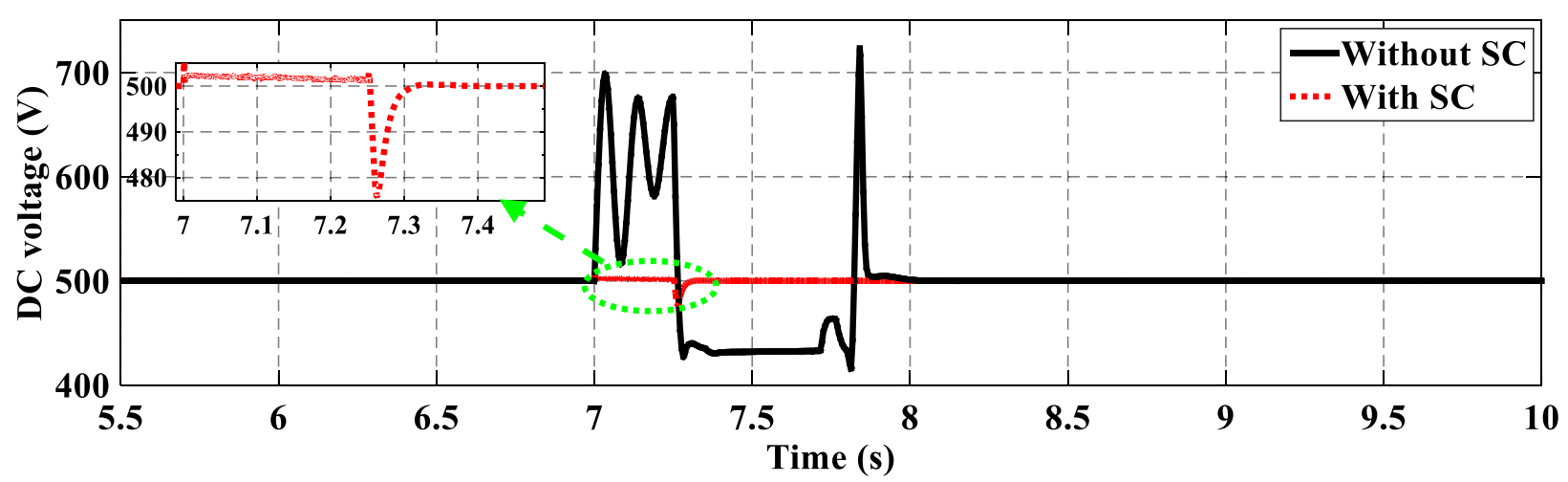

(a)

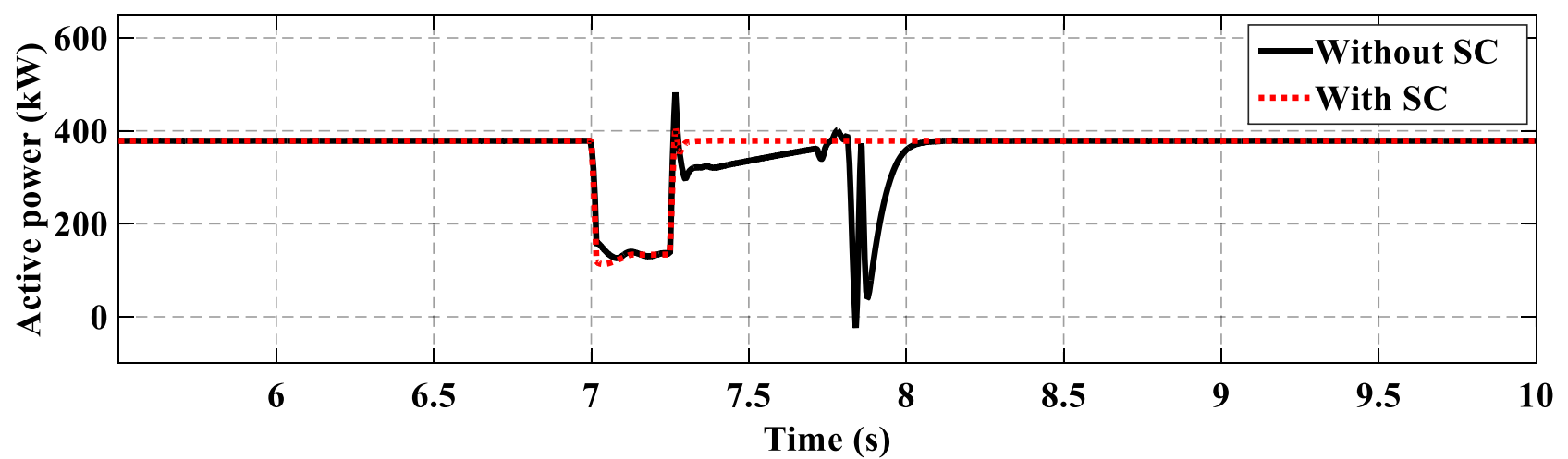

(b)

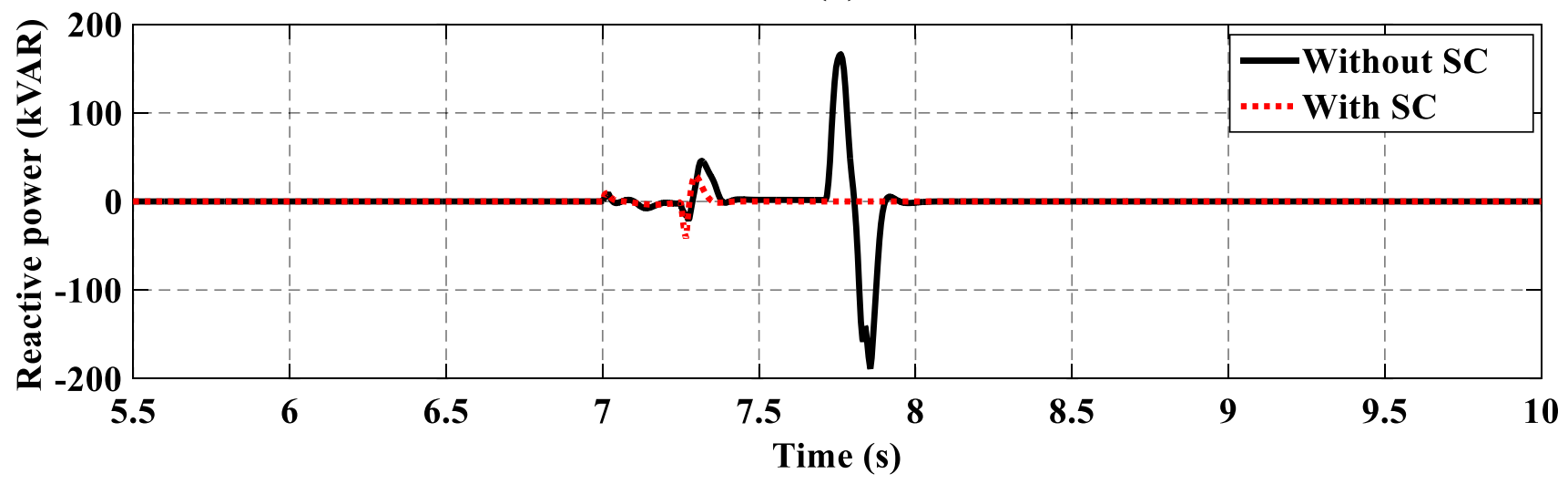

(c)

Fig. 16 Variations of system parameters during 75\% voltage dip: a DC voltage. b Active power. c Reactive power

studied. It is noticed that during SLG fault without SC, DC voltage fluctuates between 600 and $430 \mathrm{~V}$ over normal value of $500 \mathrm{~V}$, active power is oscillated between 490 and $300 \mathrm{~kW}$ over the rated value $378 \mathrm{~kW}$ and reactive power fluctuates between 30 and - 20 kVAR over zero value, also these oscillations continue after the clearance time the stabilization at its rated values. On the other hand with connecting of SC, DC voltage fluctuates between 510 and $470 \mathrm{~V}$, active power oscillates between 410 and $350 \mathrm{~kW}$ and the reactive power fluctuations are between 10 and $-20 \mathrm{kVAR}$ but, the fluctuations stabilize at rated values immediately after fault time. The impact of DLG fault without SC, DC voltage oscillates between 750 and $430 \mathrm{~V}$, active power changes between 420 and $50 \mathrm{~kW}$ and reactive power fluctuates between 150 and -180 kVAR, also at the clearance time these oscillations will still for a period before returning to rated values. However with applying of SC, DC voltage is fluctuated between 510 and $484 \mathrm{~V}$, the active power decreases to $50 \mathrm{~kW}$ and the oscillations of reactive power are between 
80 and -180 kVAR, while these fluctuations stabilize at normal values at the clearance of fault time. TLG fault without SC, DC voltage are between 780 and $430 \mathrm{~V}$, the oscillations of active power are between 400 and $0 \mathrm{~kW}$ and reactive power fluctuates between 250 and - 370 kVAR, also after fault time all these oscillations still for a time before stabilization. However with SC, DC voltage fluctuates between 510 and $490 \mathrm{~V}$, active power reduces to zero and reactive power oscillates between 100 and $-370 \mathrm{kVAR}$, then all parameters stabilize at its normal values. The simulation results of $50 \%$ voltage dip without SC show that, the oscillations of DC voltage are varied between 600 and $430 \mathrm{~V}$, the real power fluctuates between 280 and $500 \mathrm{~kW}$, after fault the oscillations continue for a time. The reactive power oscillates between 0 and 30 kVAR but also, it fluctuates at the clearance time between 160 and - 200 kVAR. Otherwise with SC, DC voltage fluctuates between 500 and $460 \mathrm{~V}$, the active power also changes between 410 and $250 \mathrm{~kW}$, reactive power oscillates between 0 and 5 kVAR and the stabilization of all parameters occurs immediately after fault clearance. Also, the applied of $75 \%$ voltage dip without SC connection is analyzed, the oscillations of DC voltage are between 700 and $430 \mathrm{~V}$, active power fluctuates between 490 and $120 \mathrm{~kW}$, then the oscillations continue for a short time after fault time. The oscillations of reactive power are varied between 50 and 0 kVAR but also, it fluctuates again between 160 and - 160 kVAR after the stabilization time. However with SC, DC voltage fluctuates between 510 and $475 \mathrm{~V}$, the active power also reduces to $120 \mathrm{~kW}$ and reactive power oscillates between 20 and $-5 \mathrm{kVAR}$, and then the parameters are stabilized at rated values after fault clearance time. The obtained results have shown the validity of the proposed technique in terms of rapidity and stability against the grid faults.

\section{Compliance with ethical standards}

Conflict of interest The authors declare that they have no conflict of interest.

\section{References}

1. Yang X, Sun L, Yuan Y, Zhao X, Cao X (2018) Experimental investigation on performance comparison of PV/T-PCM system and PV/T system. Renew Energy 119:152-159

2. Yilmaz U, Kircay A, Borekci S (2018) PV system fuzzy logic MPPT method and PI control as a charge controller. Renew Sustain Energy Rev 81:994-1001

3. Rezaei MM, Asadi H (2019) A modified perturb-and-observebased maximum power point tracking technique for photovoltaic energy conversion systems. J Control Autom Electr Syst 30:822-831

4. Khan MS, Abid M, Ali HM, Amber KP, Bashir MA, Javed S (2019) Comparative performance assessment of solar dish assisted $\mathrm{s}-\mathrm{CO}_{2}$ Brayton cycle using nanofluids. Appl Therm Eng 148:295-306

5. Ali HM, Babar H, Shah TR, Sajid MU, Qasim MA, Javed S (2018) Preparation techniques of $\mathrm{TiO}_{2}$ nanofluids and challenges: a review. Appl Sci 8:1-30

6. Sajid MU, Ali HM (2019) Recent advances in application of nanofluids in heat transfer devices: a critical review. Renew Sustain Energy Rev 103:556-592

7. Wang L, Vo Q-S, Prokhorov AV (2017) Stability improvement of a multimachine power system connected with a large-scale hybrid wind-photovoltaic farm using a supercapacitor. IEEE Trans Ind Appl 54:50-60

8. Singh A, Suhag S (2019) Trends in islanded microgrid frequency regulation-a review. Smart Sci 7:91-115

9. Belfedhal SA, Berkouk EM, Messlem Y (2019) Analysis of grid connected hybrid renewable energy system. J Renew Sustain Energy. https://doi.org/10.1063/1.5054869

10. Jacob AS, Banerjee R, Ghosh PC (2018) Sizing of hybrid energy storage system for a PV based microgrid through design space approach. Appl Energy 212:640-653

11. Hu J, Shan Y, Xu Y, Guerrero JM (2019) A coordinated control of hybrid AC/DC microgrids with PV-wind-battery under variable generation and load conditions. Int J Electr Power Energy Syst 104:583-592

12. Shi J, Xu Y, Liao M, Guo S, Li Y, Ren L, Su R, Li S, Zhou X, Tang $Y$ (2019) Integrated design method for superconducting magnetic energy storage considering the high frequency pulse width modulation pulse voltage on magnet. Appl Energy 248:1-17

13. Sun $Q$, Xing D, Yang Q, Zhang $H$, Patel J (2017) A new design of fuzzy logic control for SMES and battery hybrid storage system. Energy Proc 105:4575-4580

14. Li Y, Lei Y, Lin X, Zhu Y (2019) Research on the application of an SMES based on sliding mode control to enhance the LVRT capability of a grid-connected PV system. Electr Power Compon Syst. https://doi.org/10.1080/15325008.2019.1627612

15. Vargas U, Lazaroiu GC, Tironi E, Ramirez A (2019) Harmonic modeling and simulation of a stand-alone photovoltaic-batterysupercapacitor hybrid system. Int J Electr Power Energy Syst 105:70-78

16. Roy PKS, Karayaka HB, Yan Y, Alqudah Y (2019) Investigations into best cost battery-supercapacitor hybrid energy storage system for a utility scale PV array. J Energy Storage 22:50-59

17. Tian G, Ding X, Liu J (2011) Study of control strategy for hybrid energy storage in wind-photovoltaic hybrid streetlight system. In: 2011 IEEE international workshop on open-source software for scientific computation, pp 77-81. https://doi.org/10.1109/ ossc. 2011.6184698

18. Mohammadi P, Eskandari A, Milimonfared J, Moghani J (2018) LVRT capability enhancement of single-phase grid connected PV array with coupled supercapacitor. In: 20189 th annual power electronics, drives systems and technologies conference (PEDSTC), pp 193-198. https://doi.org/10.1109/pedstc.2018.83437 95

19. Qiu Y, Yuan C, Tang J (2019) Integrating SCESS into a ship-PV power system to mitigate power fluctuations and improve LVRT capability. Arab J Sci Eng 44:6769-6781

20. Noureldeen O, Youssef MM, Hassanin B (2019) Stability improvement of $200 \mathrm{MW}$ Gabal El-Zayt wind farm connected to electrical grid using supercapacitor and static synchronous compensator during extreme gust. SN Appl Sci. https://doi.org/10.1007/ s42452-019-0351-5 
21. Sedaghati R, Shakarami MR (2019) A novel control strategy and power management of hybrid PV/FC/SC/battery renewable power system-based grid-connected microgrid. Sustain Cities Soc 44:830-843

22. Wang X, Yu D, Le Blond S, Zhao Z, Wilson P (2017) A novel controller of a battery-supercapacitor hybrid energy storage system for domestic applications. Energy Build 141:167-174

23. Moumouni Y, Baker RJ, Souba JR (2016) Analysis of a residential 5 kW grid-tied photovoltaic system. In: 2016 Clemson university power systems conference (PSC), pp 1-4. https://doi. org/10.1109/psc.2016.7462815

24. Melhaoui M, Hirech K, Lamkaddem A, Kassmi K, Deblecker O (2019) Multilevel DC/DC converter architectures for high performance PV system. J Electr Syst 15:264-275

25. Laib I, Hamidat A, Haddadi M, Ramzan N, Olabi A (2018) Study and simulation of the energy performances of a grid-connected PV system supplying a residential house in north of Algeria. Energy 152:445-454

26. Pushpavalli M, Swaroopan NJ (2019) Maximum power tracking for PV array system using fuzzy logic controller. In: International conference on intelligent computing and applications, pp 337348. https://doi.org/10.1007/978-981-13-2182-5_32

27. Zainuri MAAM, Radzi MAM, Rahman NFA (2019) Photovoltaic boost DC/DC converter for power led with adaptive P\&O-fuzzy maximum power point tracking. In: 10th international conference on robotics, vision, signal processing and power applications, pp 245-251

28. Sahbani A (2019) Single-phase grid-connected photovoltaic system using fuzzy logic controller. In: International conference on smart innovation, ergonomics and applied human factors, pp 376-385. https://doi.org/10.1007/978-3-030-22964-1_42

29. Satif A, Hlou L, Benbrahim M, Erguig H, Elgouri R (2018) Simulation and analysis of a PV system with P and O MPPT algorithm using a PI controller for buck converter'. ARPN J Eng Appl Sci 13:3014-3022

30. Shi J, Zhang W, Zhang Y, Xue F, Yang T (2015) MPPT for PV systems based on a dormant PSO algorithm. Electr Power Syst Res 123:100-107

31. Chong LW, Wong YW, Rajkumar RK, Isa D (2016) An optimal control strategy for standalone PV system with battery-supercapacitor hybrid energy storage system. J Power Sour 331:553-565

32. Heydari E, Varjani AY (2019) A new variable step-size P\&O algorithm with power output and sensorless DPC method for gridconnected PV system. In: 2019 10th international power electronics, drive systems and technologies conference (PEDSTC), pp 545-550. https://doi.org/10.1109/pedstc.2019.8697651

33. Shang L, Zhu W, Li P, Guo H (2018) Maximum power point tracking of PV system under partial shading conditions through flower pollination algorithm. Prot Control Modern Power Syst $3: 3-38$
34. Naderipour A, AbdulMalek Z, Afrouzi HN, Ramachandaramurthy VK, Guerrero JM (2018) A novel compensation current control method for grid-connected PV inverter to improve power quality in micro-grid. In: 2018 IEEE PES Asia-Pacific power and energy engineering conference (APPEEC), pp 143-148

35. Behera RR, Thakur A (2016) An overview of various grid synchronization techniques for single-phase grid integration of renewable distributed power generation systems. In: 2016 international conference on electrical, electronics, and optimization techniques (ICEEOT), pp 2876-2880. https://doi.org/10.1109/ iceeot.2016.7755223

36. Worku MY, Abido M, Iravani R (2016) Power fluctuation minimization in grid connected photovoltaic using supercapacitor energy storage system. J Renew Sustain Energy 8:013501-1-013501-18

37. Allagui A, Freeborn TJ, Elwakil AS, Fouda ME, Maundy BJ, Radwan AG, Said Z, Abdelkareem MA (2018) Review of fractionalorder electrical characterization of supercapacitors. J Power Sour 400:457-467

38. Kondrat S, Kornyshev AA (2016) Pressing a spring: what does it take to maximize the energy storage in nanoporous supercapacitors? Nanoscale Horiz 1:45-52

39. Jiancheng T, Haili G, Guangzong C (2017) LVRT control strategy of VSC-HVDC connected large PV plant. In: 2017 China international electrical and energy conference (CIEEC), pp 504-509. https://doi.org/10.1109/cieec.2017.8388499

40. Luta DN, Raji AK (2019) Optimal sizing of hybrid fuel cell-supercapacitor storage system for off-grid renewable applications. Energy 166:530-540

41. Vasant LG, Pawar V (2017) Optimization of solar-wind energy system power for battery charging using MPPT. In: 2017 International conference on energy, communication, data analytics and soft computing (ICECDS), pp 1308-1310. https://doi. org/10.1109/icecds.2017.8389656

42. Noureldeen O, Youssef MM (2018) Constant power-control of DFIG wind farm with LVRT improvement during extreme gust using super-capacitors. In: 2018 twentieth international middle east power systems conference (MEPCON), pp 515-521. https:// doi.org/10.1109/mepcon.2018.8635231

43. Solar Energy Plants (2017) Grid connection code in addition to the Egyptian transmission grid code (ETGC). http://www.nrea. gov.eg/. Accessed Mar 2017

Publisher's Note Springer Nature remains neutral with regard to jurisdictional claims in published maps and institutional affiliations. 